د. محهود عبد المجيد عساف د. علاء محمل الغماري

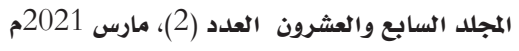

دور مشروع التصصين المصتمعي الفلسطيني في تمزيز الجبهة الدافلية وسبل تفميله المفينه

الالتعـتلام : 3 / مارس / 2021

التحكيــم : 10 10/مارس / مارس / 2021

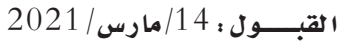

د. محمود عبل المجهيل عساف (1،)

د. علاء محمد الخهاري 2

(c) 2021 University of Science and Technology, Yemen. This article can be distributed under the terms of the Creative Commons Attribution License, which permits unrestricted use, distribution, and reproduction in any medium, provided the original author and source are credited.

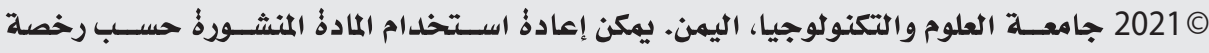
مؤسسة المشاع الإبداعي شريطة الاستشهاد بالمؤلف والمجلة. 
د. محمود عبد المجيد عساف د. د. علاء محمد الغماري

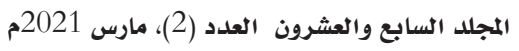

دور مشروع التحصين المجتمعي الفلسطيني في تعزيز الجبهة الداخلية وسبل تفعيله

الملخص:

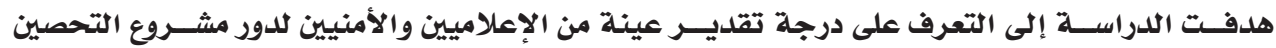

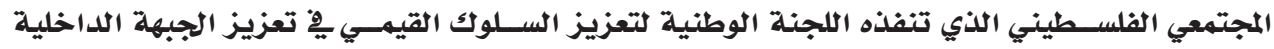

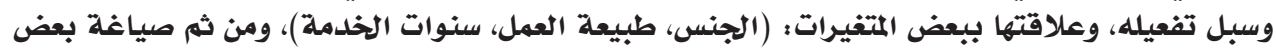

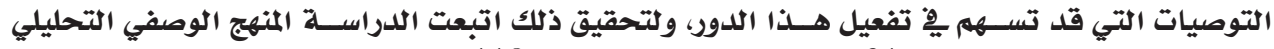

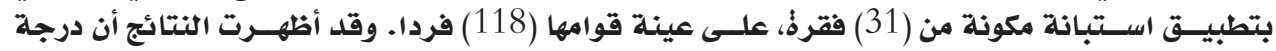

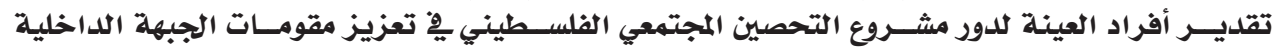

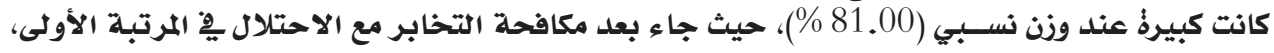

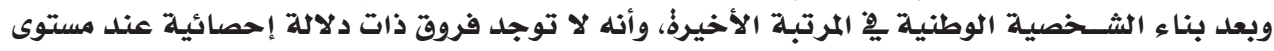

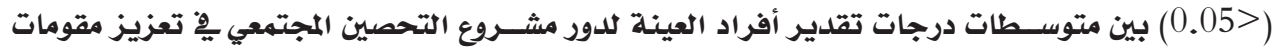

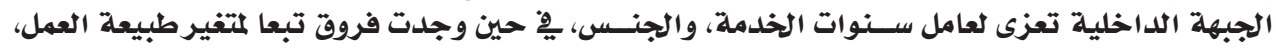

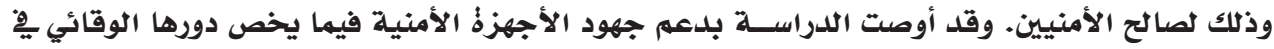

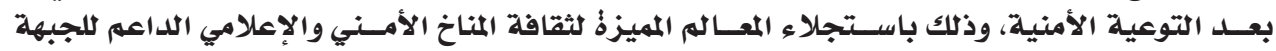

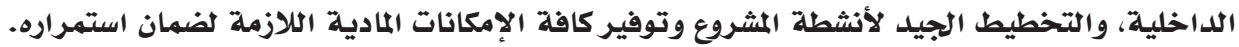
الكلمات المفتاحية : الجبهة الداخلية، سبل التفعيل، مشروع التحصين المجتمعي. 


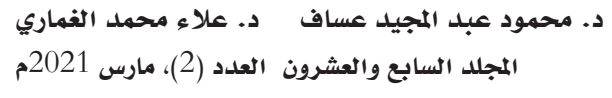

\title{
Role of Community Protection Project in Strengthening Palestinian Home Front and Means for Activation
}

\begin{abstract}
:
This study aimed to identify the assessment degree of a sample of media and security people regarding the role of the community protection project in Palestine, which is being implemented by the National Commission for Strengthening Values and Behaviors in the community, in relation to some variables (gender, work type and years of experience). The study also attempted to propose a set of recommendations that might contribute to activating the role of community protection. To achieve this, the descriptive analytical method was followed and a questionnaire of 31 items was used to collect data from a sample of 118 participants. The study findings revealed that the degree assessment of the role of community protection in supporting home front requirements was high at a relative weight of $(81 \%)$. The first dimension (communication with the occupying forces) received the highest degree, whereas (building national affiliation) received the lowest degree. There were no statistically significant differences $(<0.05)$ among the participants attributed to years of experience and gender. On the other hand, there were differences attributed to work type in favor of security people. The study stressed the need to support security organizations in their pursuit to raise security awareness by encouraging the culture of media and security climate that supports home front. It was also recommended that project activities should be well-planned and all requirements should be made available to make the project sustainable.
\end{abstract}

Keywords: home front, activating means, community protection project. 
د. محمود عبد المجيل عساف د. دملاء محمد الغماري

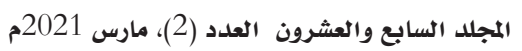

\section{المقدمة:}

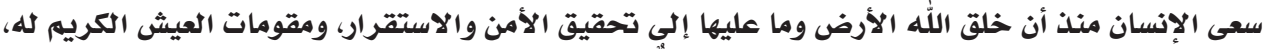

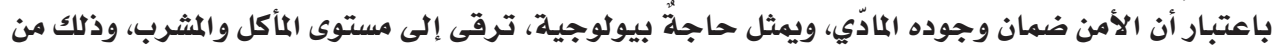

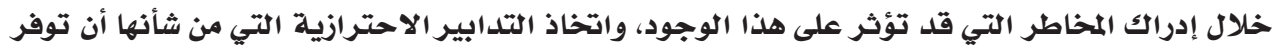

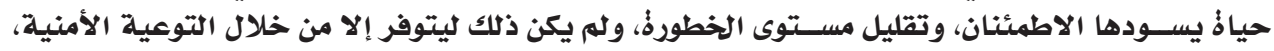
والتربية السياسية والمجتمعية.

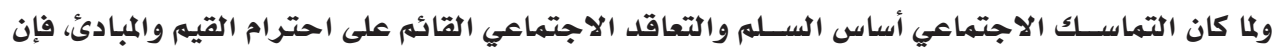

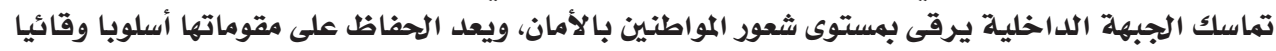

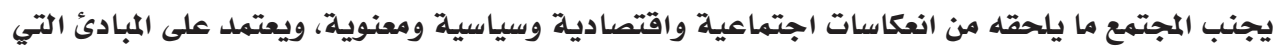

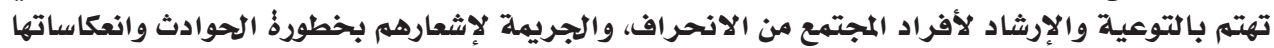

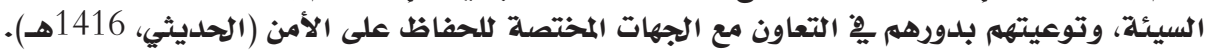

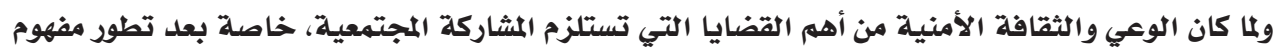

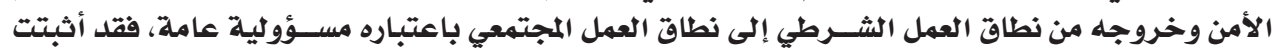

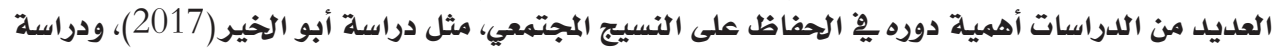

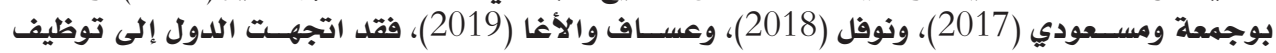

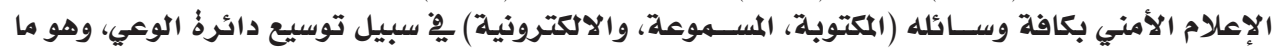
أكدته دراسة قيراط (2017).

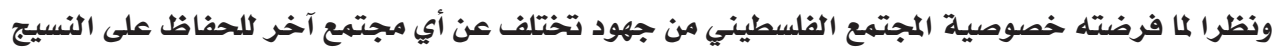

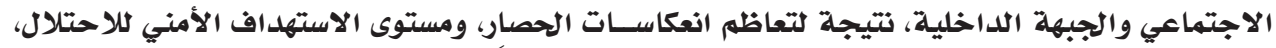

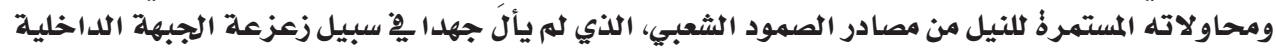

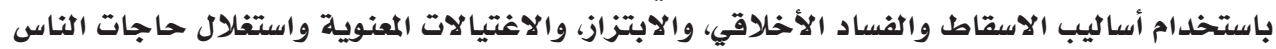

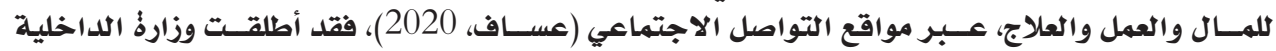

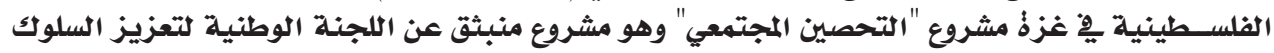

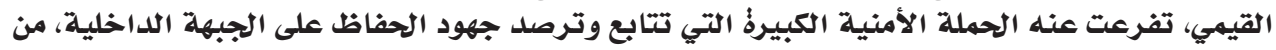

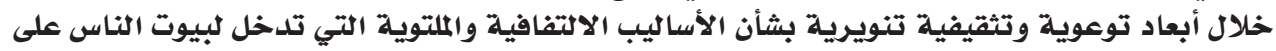

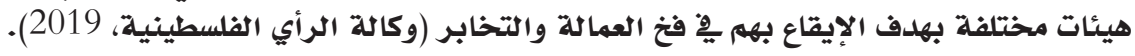

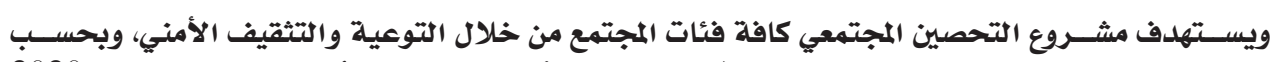

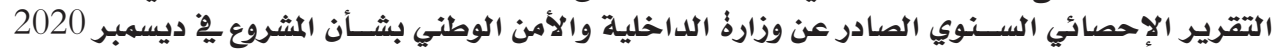

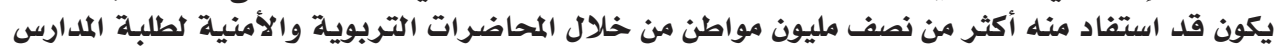

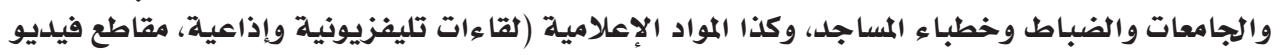
ورسوم كاريكاتيرية، ومطبوعات) (وزارةٌ الداخلية والأمن الأنواد الوطني، 2020).

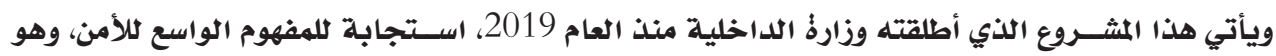

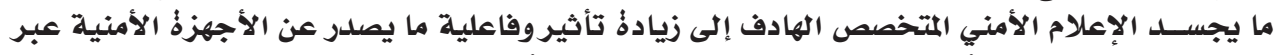

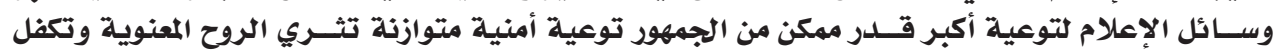

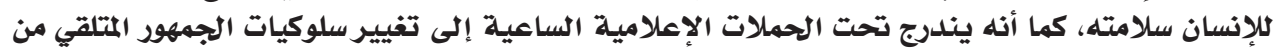

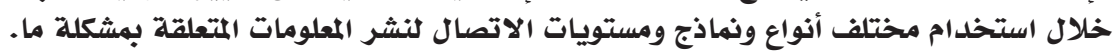

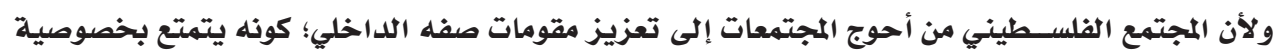

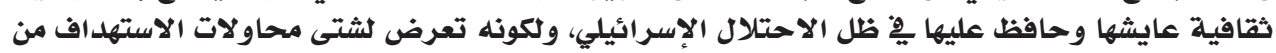

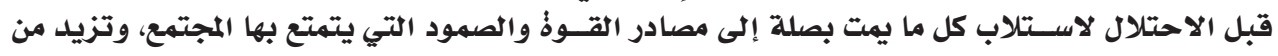


د. محهود عبد المجيد عساف د. د. علاء محمد الغماري

$\dot{0}$

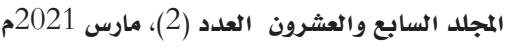

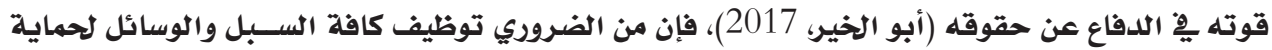

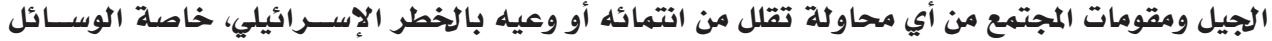

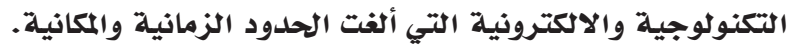

الخلفية النظريـة للدراسة :

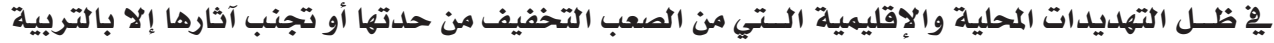

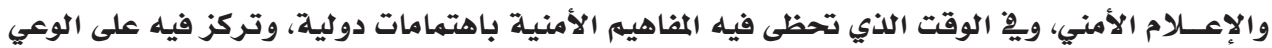

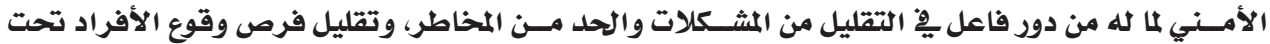

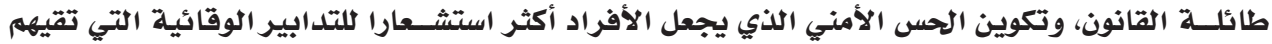

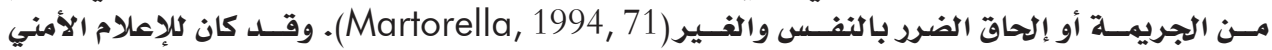

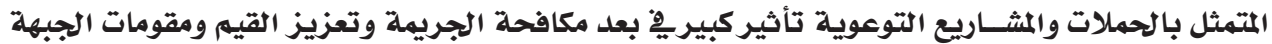

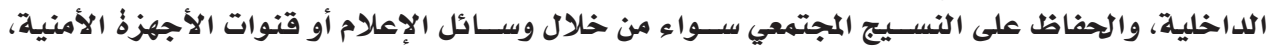

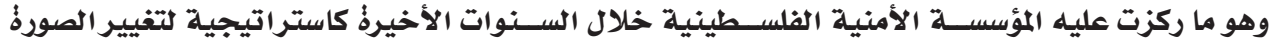

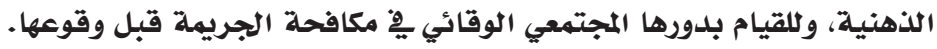

ولما كان المجتمع الفلسـطيني من المجتمعات المحافظة الذي تقل فيه الجريمة مقارنة بالمجتمعات الأخرى،

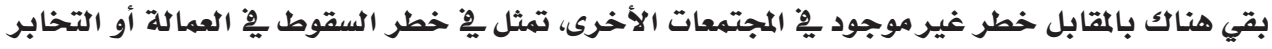

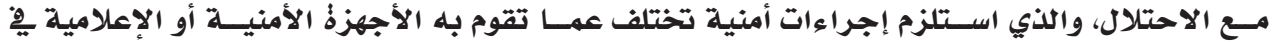

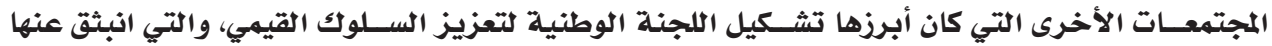

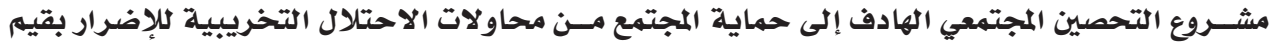

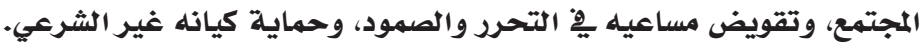

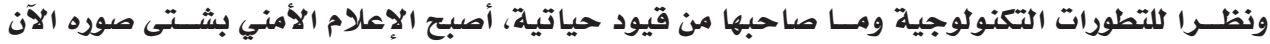

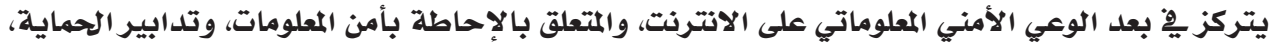

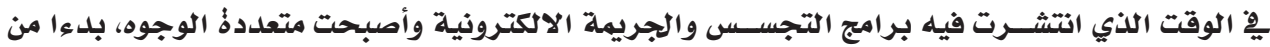

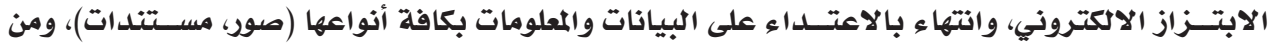

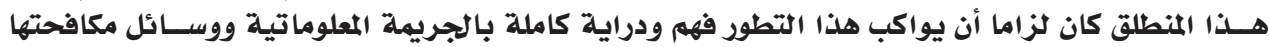
.(Thakur, 2004)

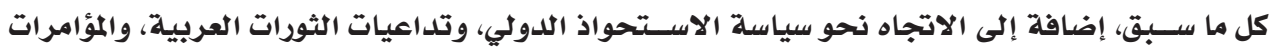

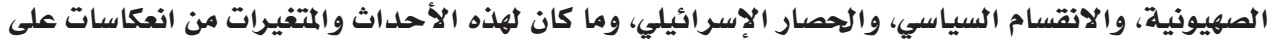

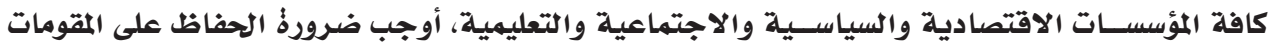

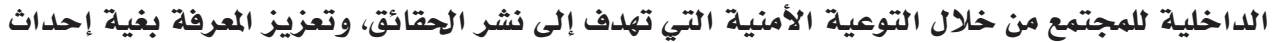

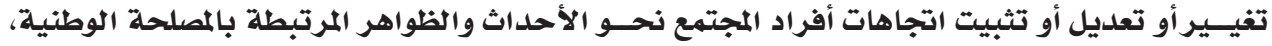

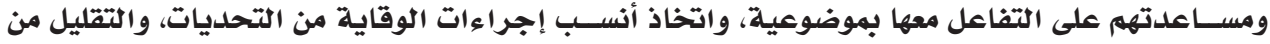
آثارها السلبية المحتملة.

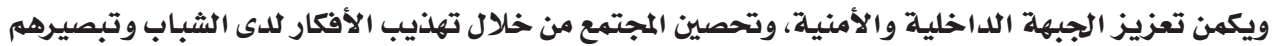

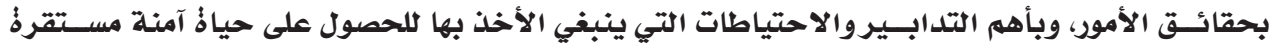

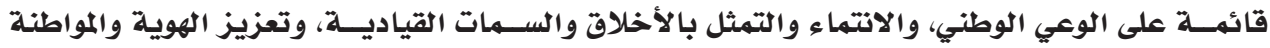

$$
\text { (إبراهيم، 1408هـ). }
$$

مقومات الجبهة الداخلية للمجتهع الفلسطيني؛

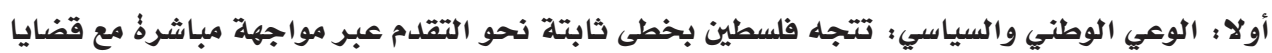

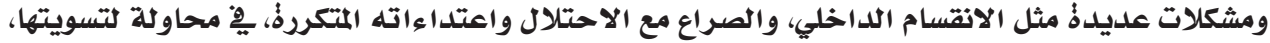


ولابد أن يسبق أية محاولة للوصول إلى الحلول ثلذه القضايا والمشكلات، الوعي الوطني بطبيعة الأوضاع

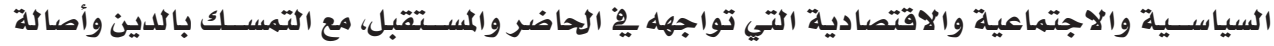

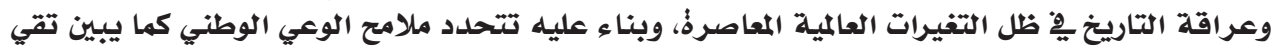

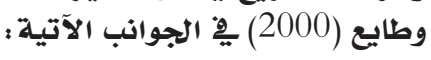

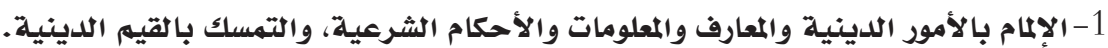

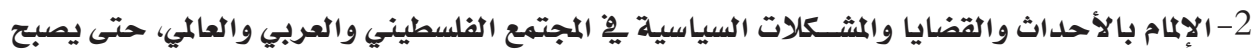

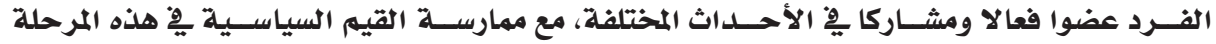

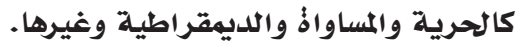

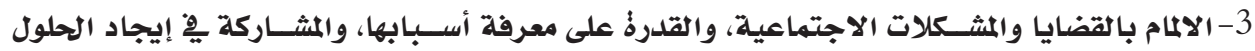

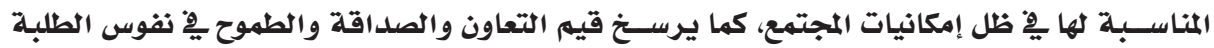

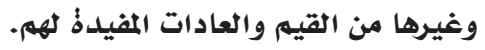

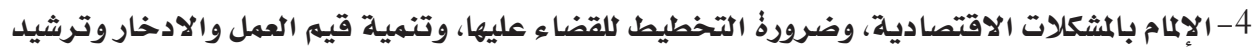

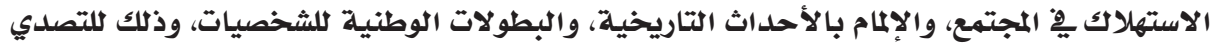

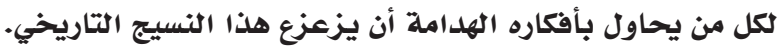

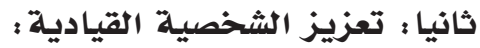

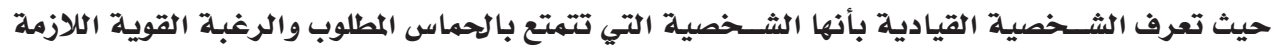

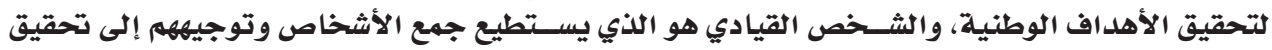
هذه الأهداف؛ لذذلك تتميز الشخصية القيادية والثما يبين الضامن (2012) بالآتي؛

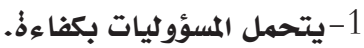

$$
\begin{aligned}
& \text { 2- لديه ثقة كبيرة بنفسه. }
\end{aligned}
$$

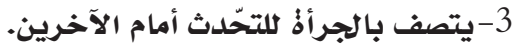

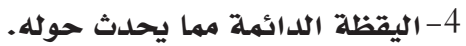

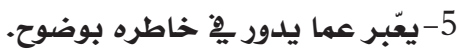

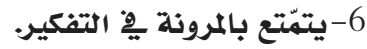

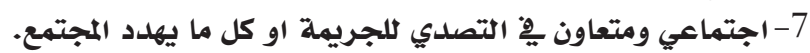

8- يشارك يِّ العديد من الأنشطة، ويدير الأنشطة التي يشارك فيها.

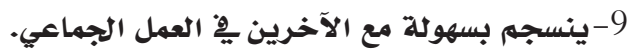

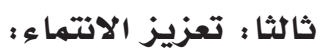

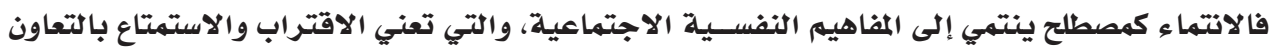

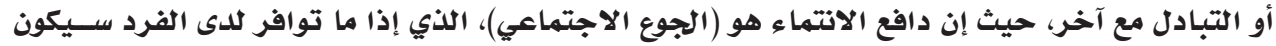

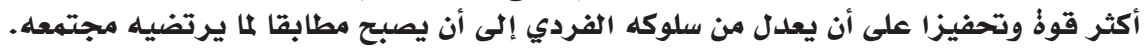

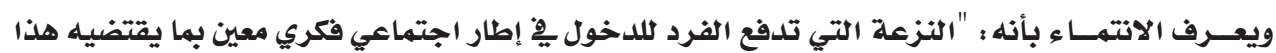

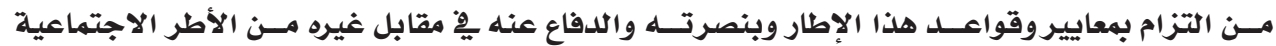

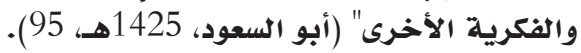

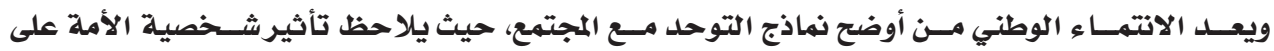

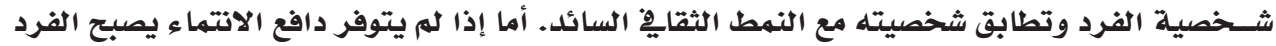

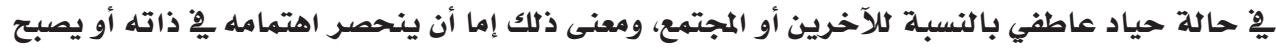

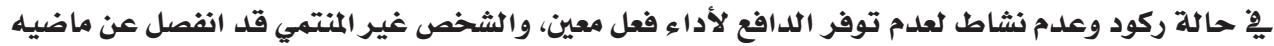

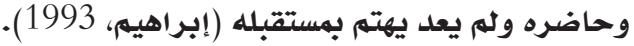


د. محهمود عبد المجيد عساف د. علاء محمد الغهاري

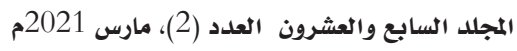

وبناء عليه يتجلى دور الإعلام الأمني ِِّ تعزيز الانتماء والولاء، كما يبين أبو فودةُ (2006) ِِّ الآتي:

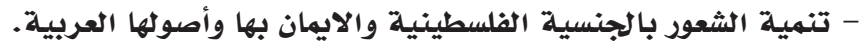

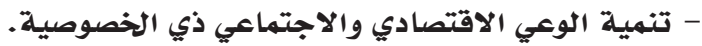
- التبصير بالأخطار التي تهلدد وطنه وتحصينه من المخاطر الصهيونية (التخابر).

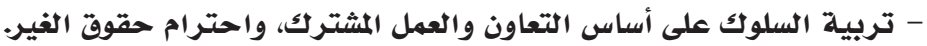

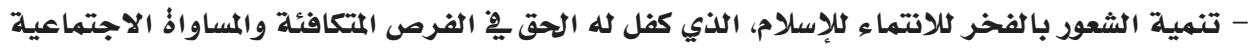
والسياسية. رابعاء تعزيز الهوية الوطنية والثقافية ؛

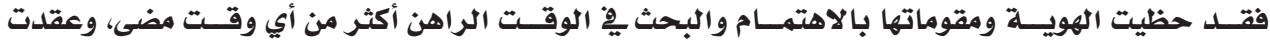

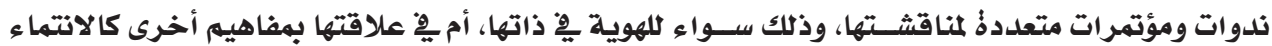
والشخصية القومية والتراث وغيرها من مفاهيم لها صلة وثيقة بالهوية والذاتية.

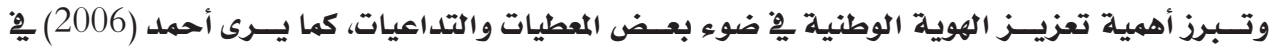
الآتي:

ه التحصين ضد عمليات الاستقطاب السياسي والفكري المنحرف، والعمالة (التخابر). ه التدريب على المشاركة الفاعلة يِّاِ الحياذٌ السياسية. ه إنماء قيه الحرية والمسئولية والوطنية والقوةٌ فِ نفوس الشئه الشباب. ه تعميق الاعتزاز بالوطن والافتخار بالانتماء إليه، والتضحية من وأجله وايه. ه التدريب على التعامل مع الأزمات والحروب. ه التوعية بتاريخ الوطن وتراثه والحفاظ على ممتلكاته.

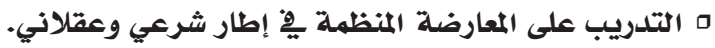
ه التحفيز للحفاظ على ثقافة المجتهع وخصوصيتها.

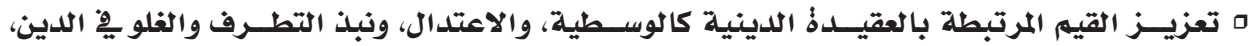
والتسامح الديني والحوار الديني.

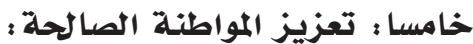

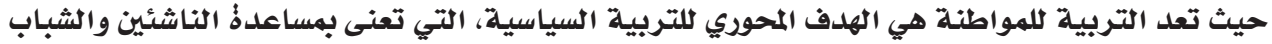

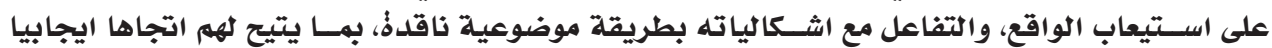

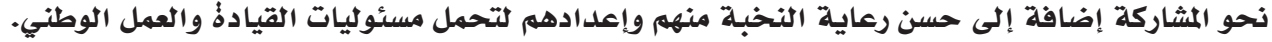

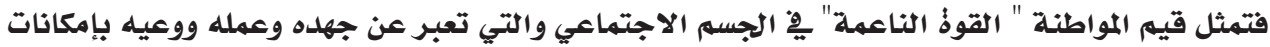

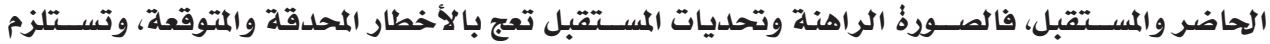

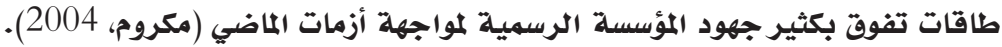
وتهدف التربية للهواطنة الصالحة إلى : - تثبيت وترسـيخ مجموعة من المبادئ منها الإحســاس بالهوية والتهائه والتسامح والحوار المبني على الاحترام

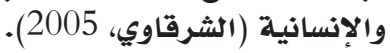

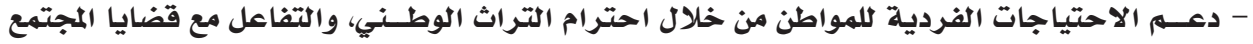

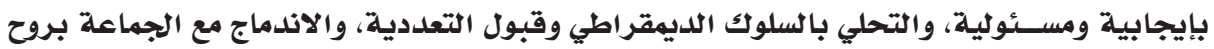
التضامن، وحب العمل، وتكوين مواقف ايجابية وملية نحو الوطن والمواطن (عطية، 2008). 
ويمكن للباحثين إضافة أهداف تربوية أخرى للمواطنة الصالحة يِّ فلسطين، هي: - التدريب على المشاركة يِّ القرارات التي تؤثر يِّن البيئة المحيطة. - تزويد الفرد بفهم واع لواقع النظام السياسي.

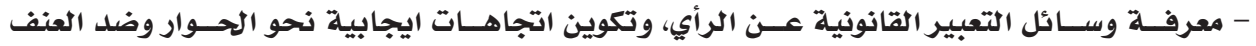
والتطرف. - تنمية القدرات على اكتساب ومعالجة المعلومات المتصلة بشئون الجماعات والأحزاب.

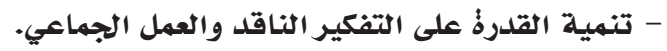

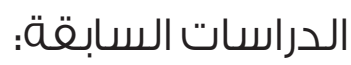

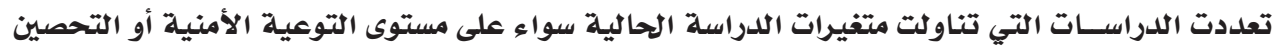

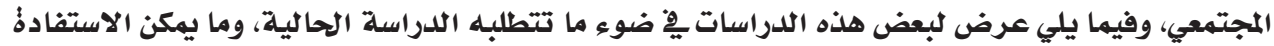
منها.

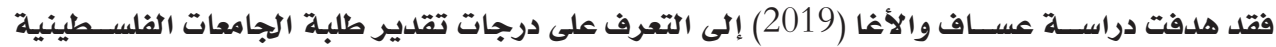

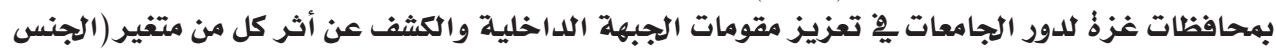

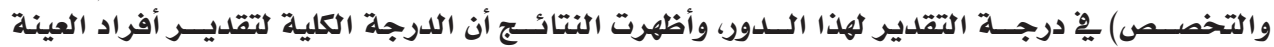

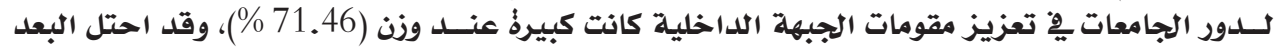

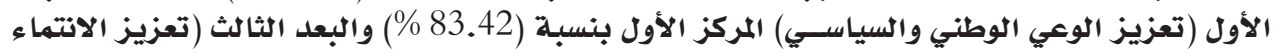

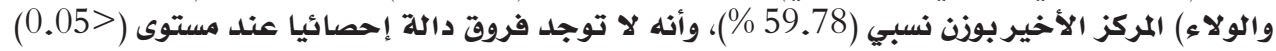

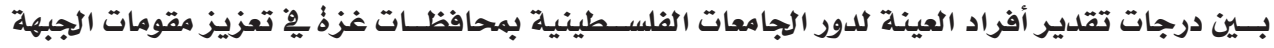

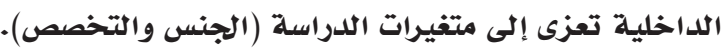

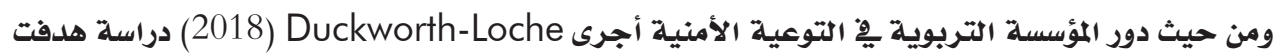

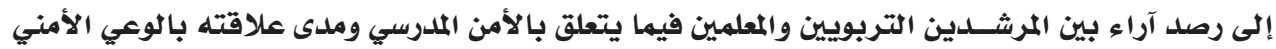

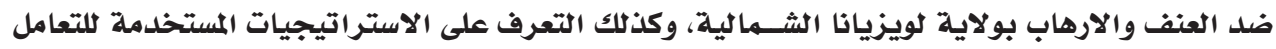

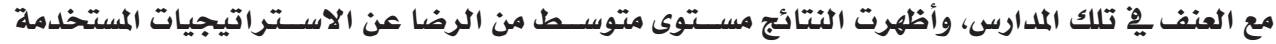

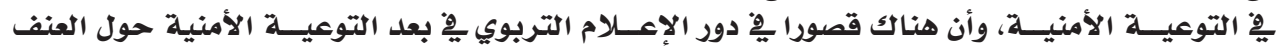

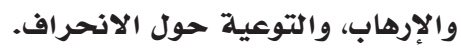

وقد هدفت دراسة بلدرخان وقطاوي (2017) إلى استقصاء آراء طلبة كليات الآداب يِّ الجامعات الأردنية

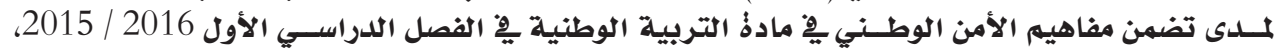

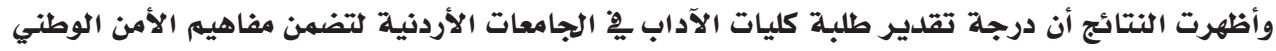

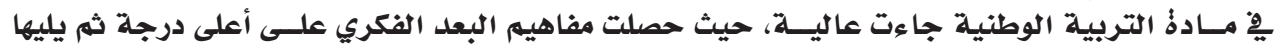

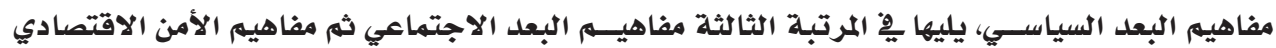

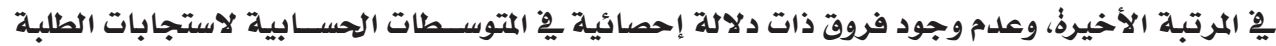

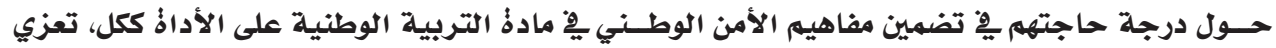
لمتغيري الجنس والمستوى الدراسي.

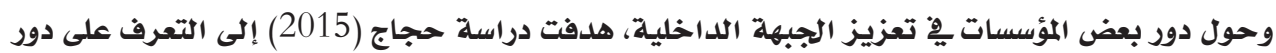

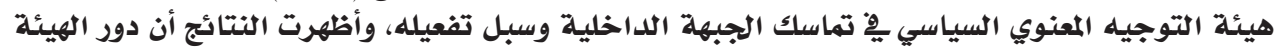

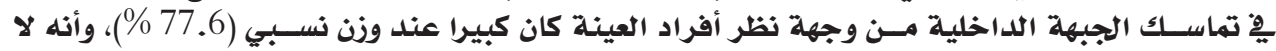

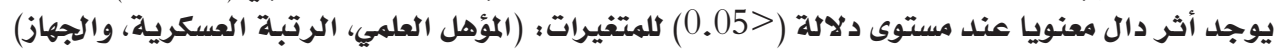

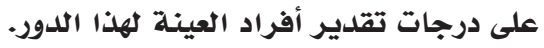


د. محمود عبد المجيد عساف د. د. علاء محمد الغماري

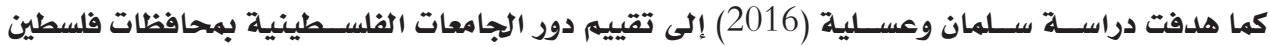

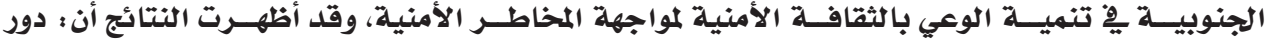

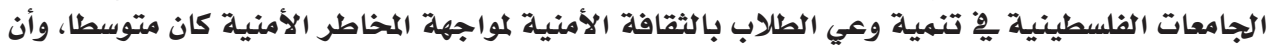

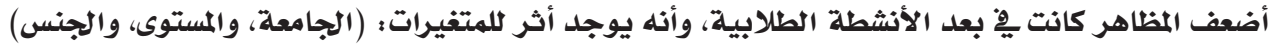

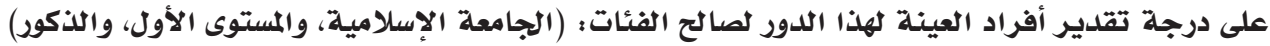
على الترتيب.

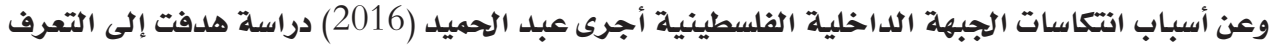

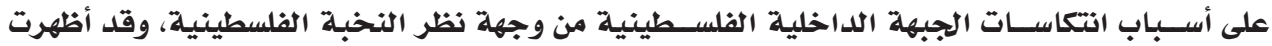

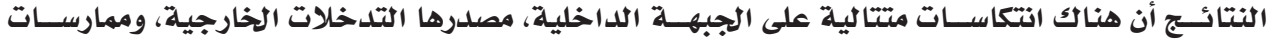

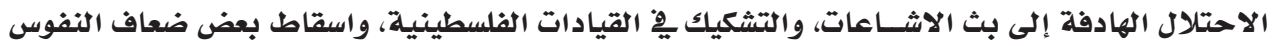

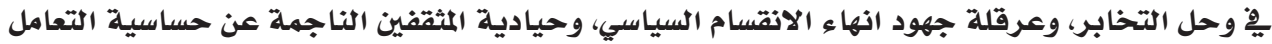
مع حريـة الرأي والتعبير.

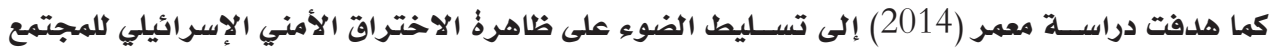

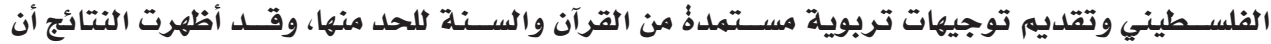

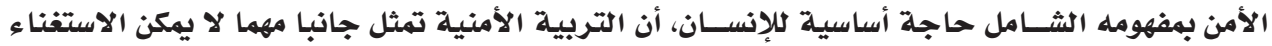

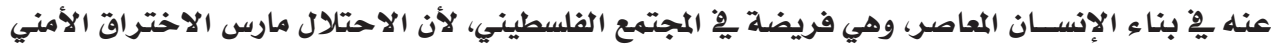

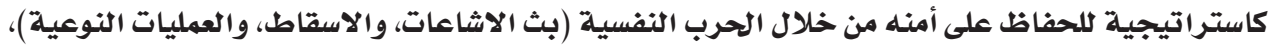

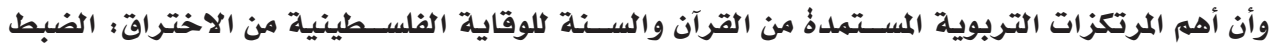

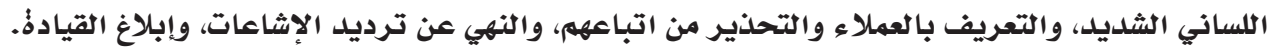

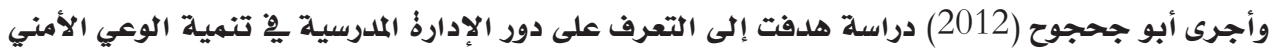

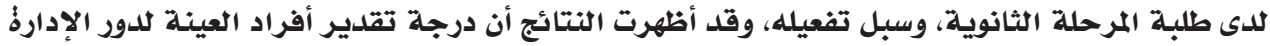

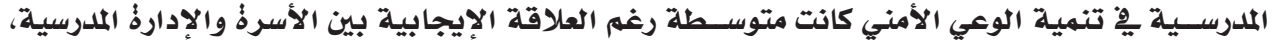

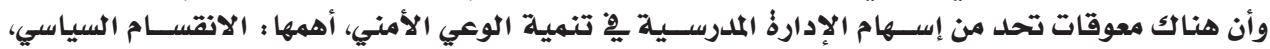

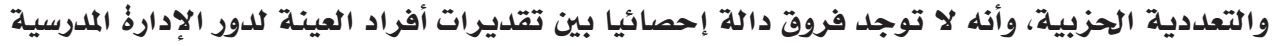

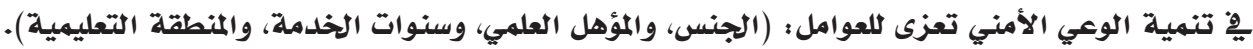

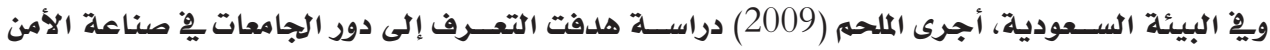

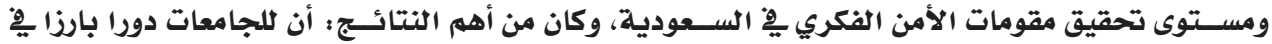

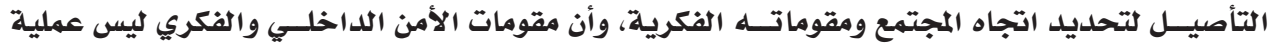

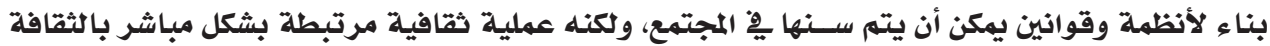

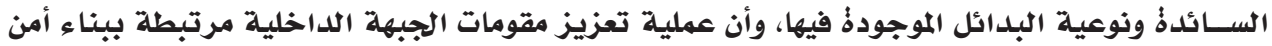

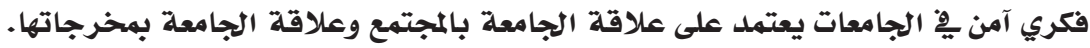

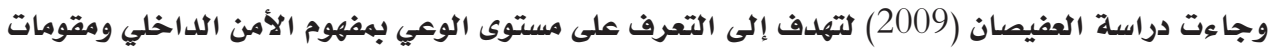

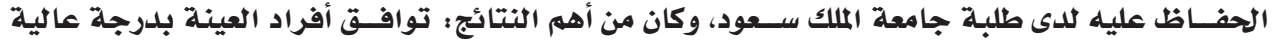

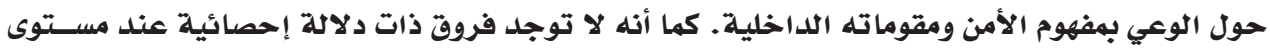

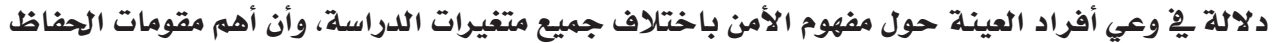

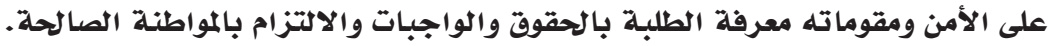

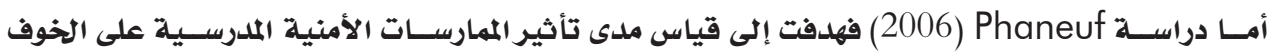

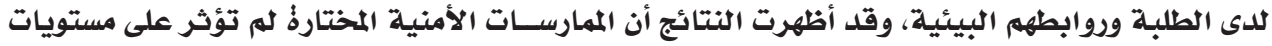

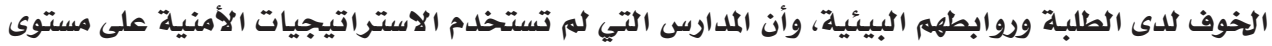

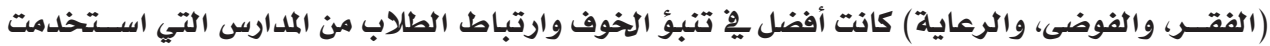




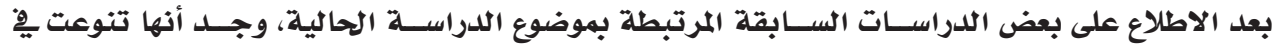

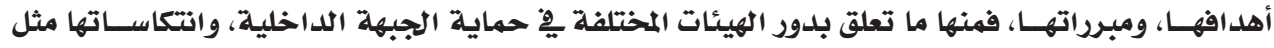

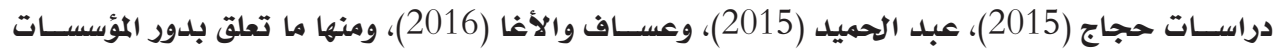

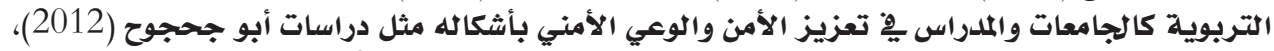

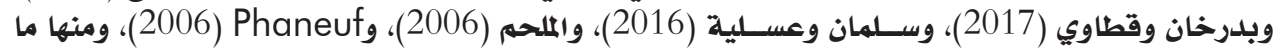

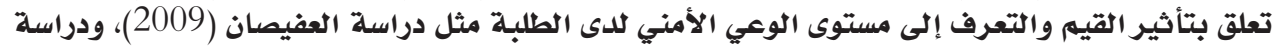

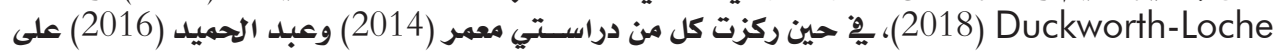
أسباب انتكاسات الجبهة الداخلية.

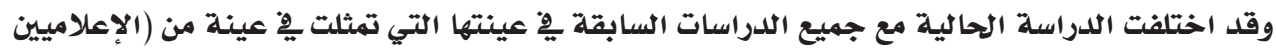

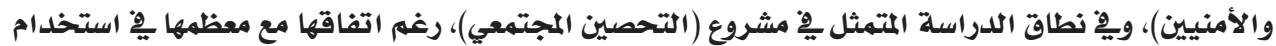

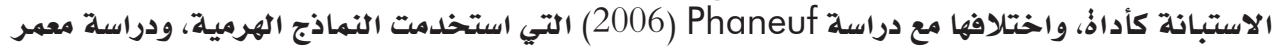

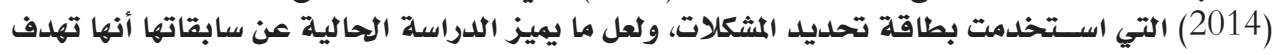

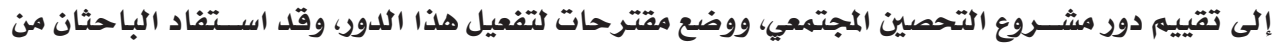

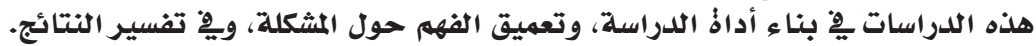

مشكلة الدراسة وتساؤلاتها:

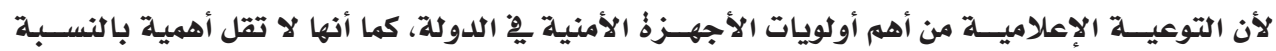

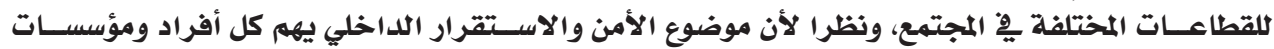

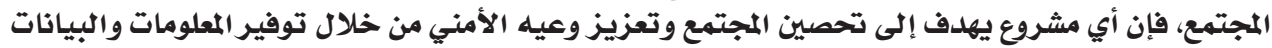

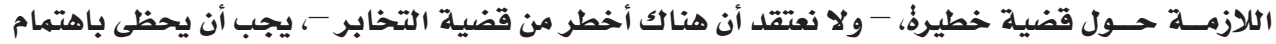

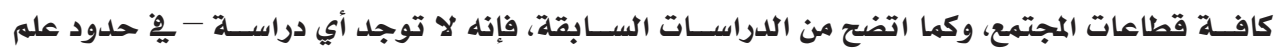

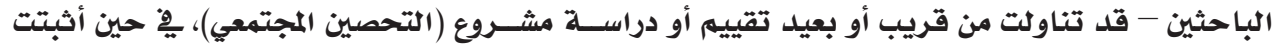

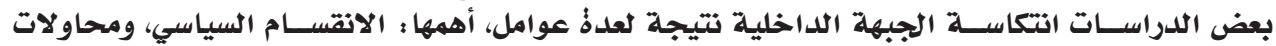

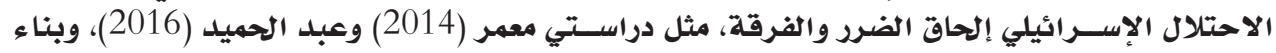

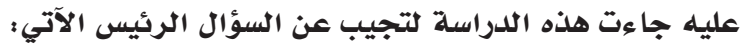

ما دور مشـروع التحصين المجتمعي الذي تنفذه اللجنة الوطنية لتعزيز السلوك القيهي يِّ تعزيز الجبهة

الداخلية وسبل تفعيله؟ مأدوع التحصن

ويتقرع من هذا السؤال، التساؤلات الفرعية الآتية ؛

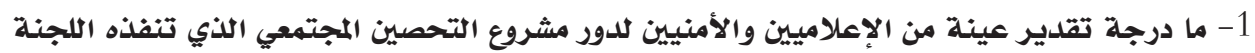

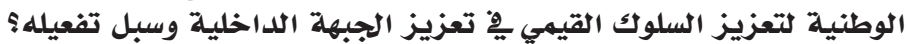

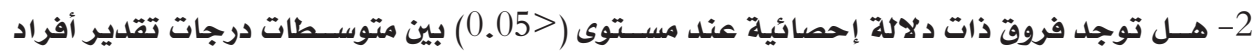

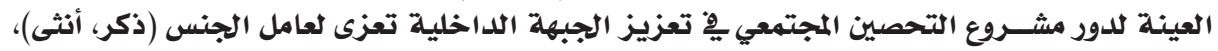

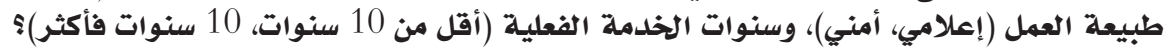

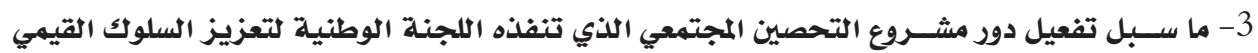

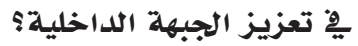


د. محمود عبد المجيد عساف د. دملاء محمد الغماري

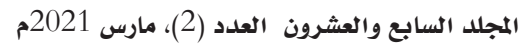

$$
\text { أهداف الدرافة الدراسة إلى: }
$$

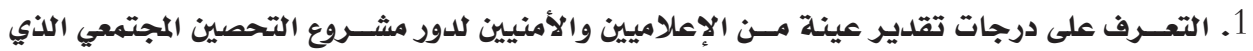

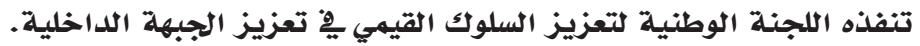

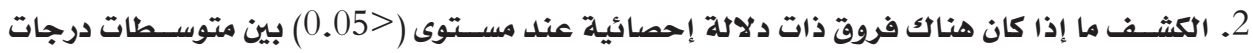

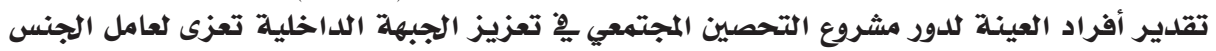

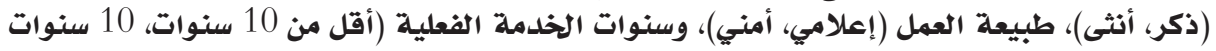

فأكثر)

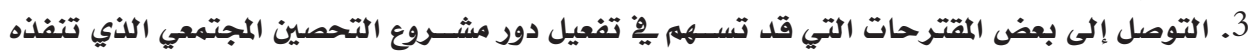

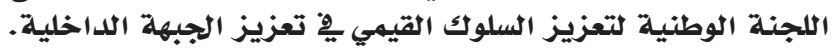

$$
\text { أهمية الهدراسة المهية: }
$$

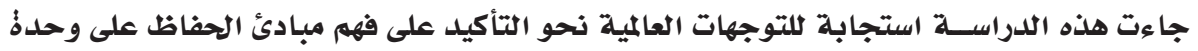

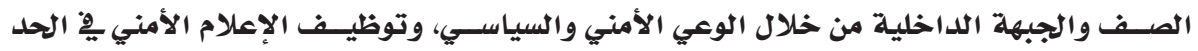

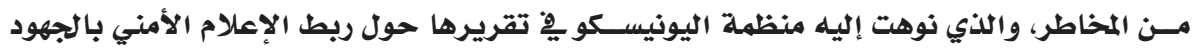

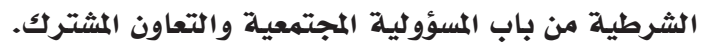

كما أن أهمية هذه الدراسة جاءت من أهمية وندرةٌ موضوعها فهي تعلد الدراسة الأولى من نوعها-ِيف

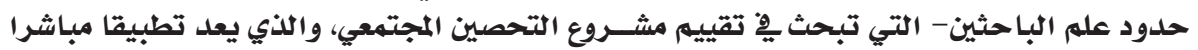

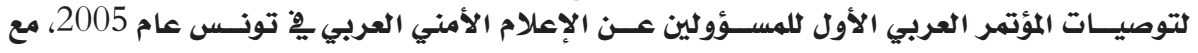

الاختلاف فِّوطبيعة المخاطر.

الأهمية التطبيقية :

- قد تفيد نتائج هذه الدراسة إِّة تقييم المشروع من وجهة نظر الأمنيين والإعلاميين باعتبارهم من أكثر

$$
\text { الفئات ارتباطا بتنفيذ المشروع. }
$$

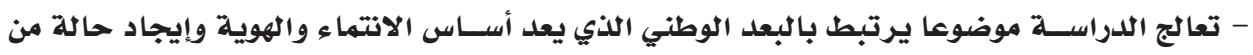
اليقظة المستمرةٌ تجاه ممارسات الاحتلال.

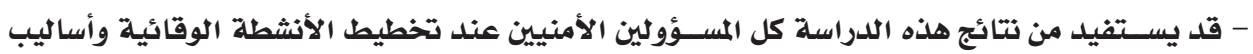

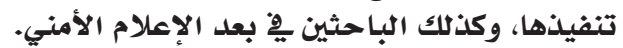

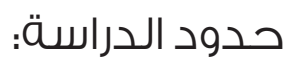

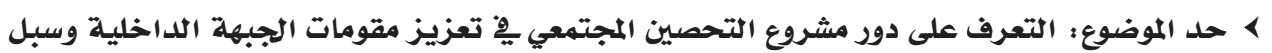

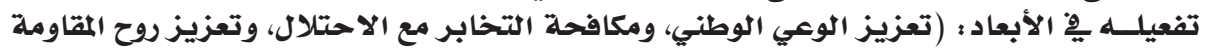

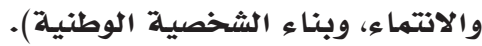

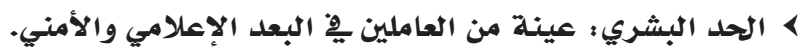

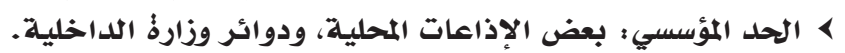

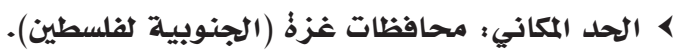

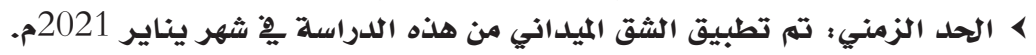




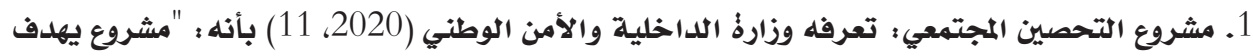

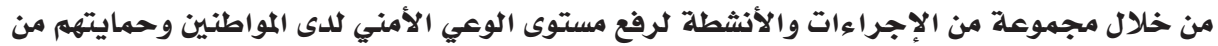

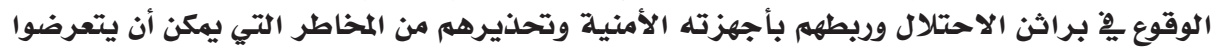

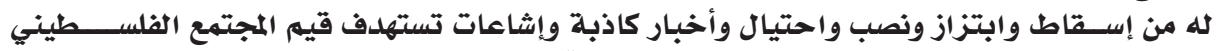

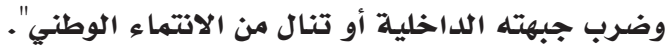

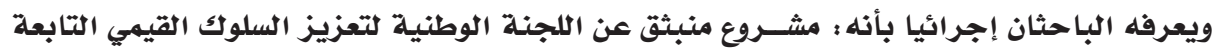

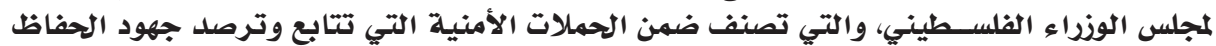

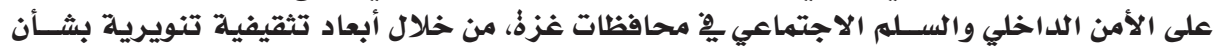

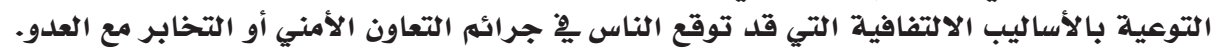

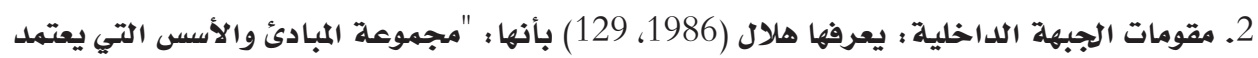

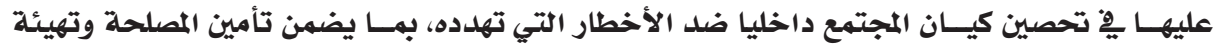

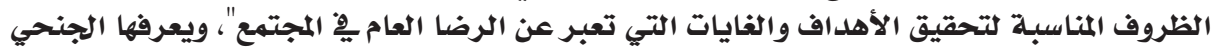

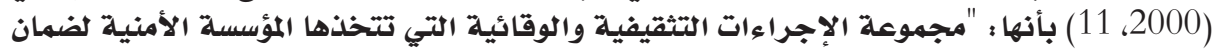

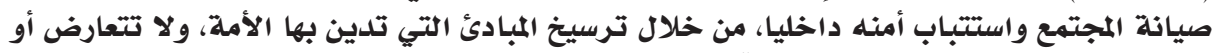

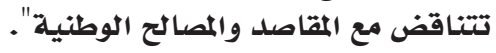

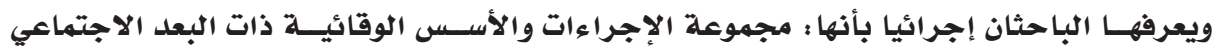

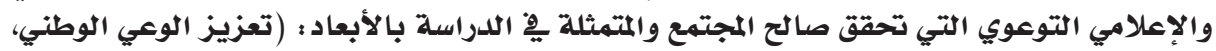

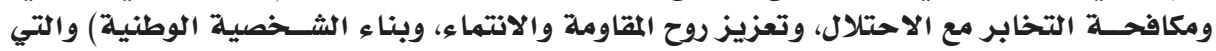

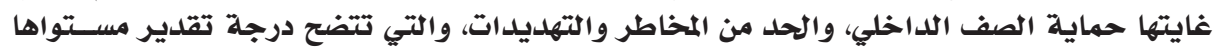

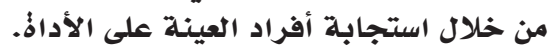

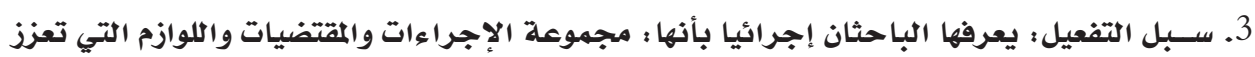

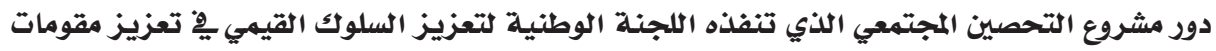

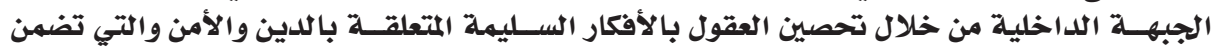

إجراءات الدراسة:

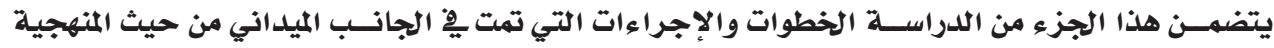

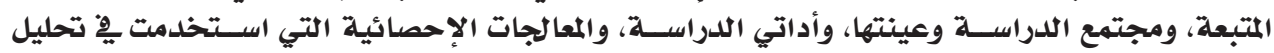

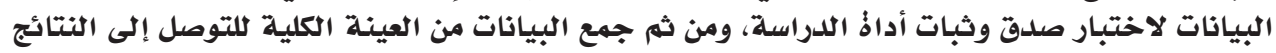

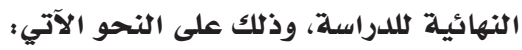

$$
\text { منهج الدراسة: }
$$

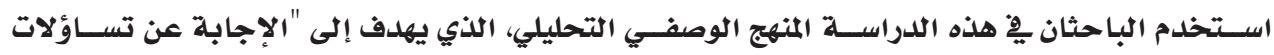

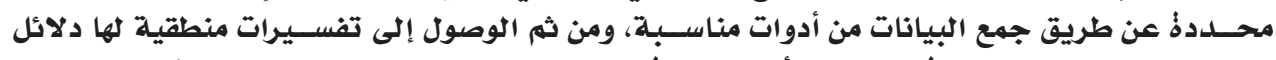

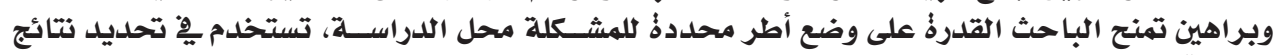

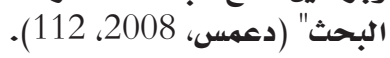

$$
\text { مجتهع الدراسة وعينتها : }
$$

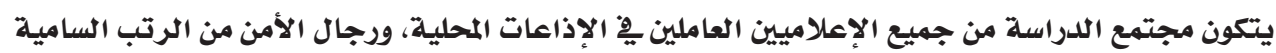

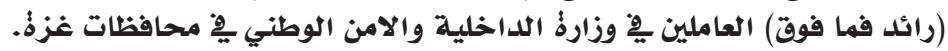


د. محهمود عبد المجيد عساف د. علاء محمد الغهاري

المجلد السابع والعشرون العدد (2)، مارس 2021م موديل

1. العينة الاستطلاعية : تكونت من (30) مبحوثا من الجنسين تم اختيارهم بالطريقة العرضية بهدف

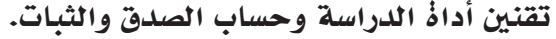

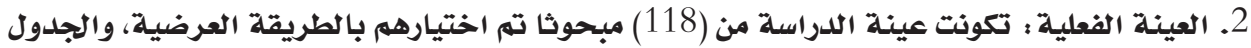

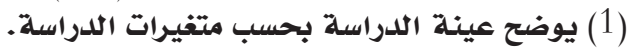

جدول (1): توزيع أفراد العينة بحسب متغيرات الدراسة

\begin{tabular}{|c|c|c|c|}
\hline النسبـة المئويـة & العلدد & البيان & المتفير \\
\hline$\% 91.5$ & 108 & 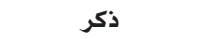 & الجنس \\
\hline$\% 8.5$ & 10 & 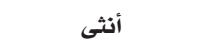 & \\
\hline$\% 100$ & 118 & المجموع & \\
\hline$\% 78.8$ & 93 & أمني & مجال العمل \\
\hline$\% 21.2$ & 25 & إعلامي & \\
\hline$\% 100$ & 118 & المجموع & \\
\hline$\% 28$ & 33 & أقل من 10 سنوات & سنوات الخدمة الفعلية \\
\hline$\% 72$ & 85 & 10 سنوات فأكثر & \\
\hline$\% 100$ & 118 & المجموع & \\
\hline
\end{tabular}

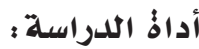

بعد الاطلاع على الأدب التربوي وبعض الدراسات الدات السابقة ذات العلاقة، واستطلاعر رأي عينة من المتخصصين

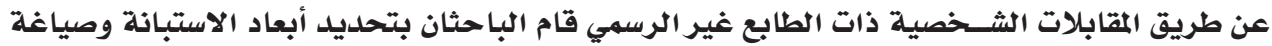

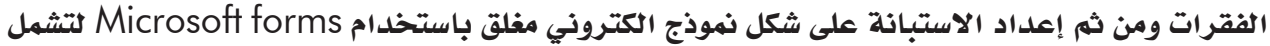

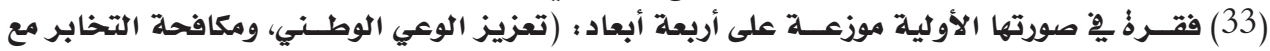

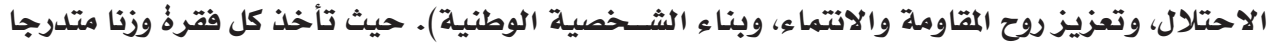

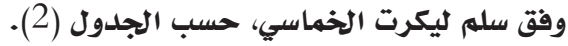

جدول (2): مقياس ليكرت الخماسي (2) بلدي

\begin{tabular}{|c|c|c|c|c|c|}
\hline صغيرةٌ جلدا & صغيرة & متوسطة & كبيرةٌ & كبيرةٌ جدا & درجة الموافقة \\
\hline 1 & 2 & 3 & 4 & 5 & الدرجة \\
\hline
\end{tabular}

اعتهد الوسط الحسابي يِّ تصحيح الفقرات بحيث تشير الدرجة المنخفضة إلى تلني الموافقة على ما جاء

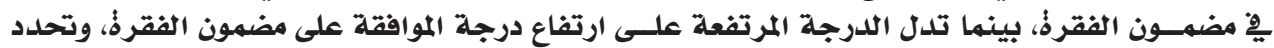

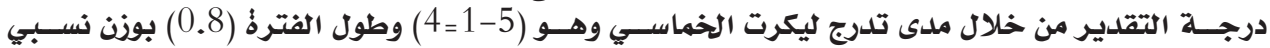

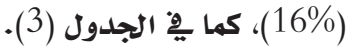

جلدول (3) : درجات التقدير لفقرات أبعاد أداذ الدراسة

\begin{tabular}{|c|c|c|}
\hline درجة الاحتياج & الوزن النسبي & طول الخلية \\
\hline ضعيفة جدا & من 20 إلى 36 & $1.8-1$ \\
\hline ضعيفة & أكبر من 36 إلى 52 & $2.6-1.8$ \\
\hline متوسطة & أكبر من 52 إلى 68 & $3.4-2.61$ \\
\hline كبيرة & أكبر من 68 إلى 84 & $4.2-3.41$ \\
\hline كبيرة جدا & أكبر من 84 إلى 100 & $5-4.21$ \\
\hline
\end{tabular}

صدق الاستبانة : مانة

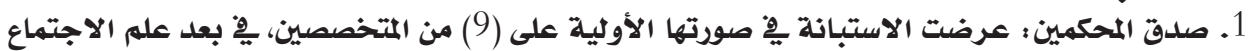

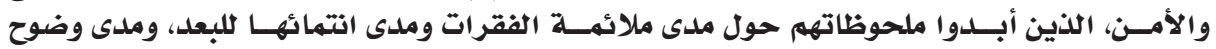

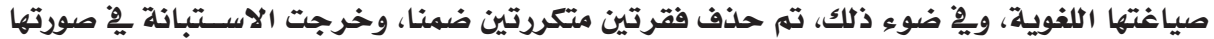

$$
\text { النهائية بـ (31) فقرة. }
$$


د. محمود عبد المجيد عساف د. دملاء محمد الغماري

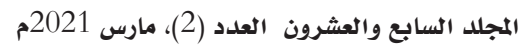

2. صدق الاتساق الداخلي: بعد تطبيق الاستبانة على العينة الاستطلاعية (من خارج العينة الأصلية)

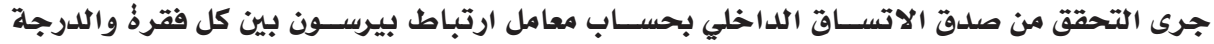
الكلية للبعل، والجدول التحق من (4) يوضح ذلانك.

جدول (4): معامل الارتباط بين كل فقرةٌ من فقرات المحور والدرجة دولة الكلية للبعد الذي تتبع له

\begin{tabular}{|c|c|c|c|c|c|c|c|c|}
\hline مستوى الدلاية & الارتباط معاط & r & مستوى الدلاية & الارتباط معاط & r & مستوى الدلاية & الارتباط معاط & r \\
\hline & & & & & & \multicolumn{3}{|c|}{ البعد الأول : تعزيز الوعي الوطني } \\
\hline 0.000 & $0.773^{\text {** }}$ & 3 & 0.000 & $0.843^{* *}$ & 2 & 0.000 & $0.672^{* *}$ & 1 \\
\hline \multirow[t]{2}{*}{0.000} & $0.729^{* *}$ & 6 & 0.000 & $0.762^{* *}$ & 5 & 0.000 & $0.793^{* *}$ & 4 \\
\hline & & & & & & 0.000 & $0.775^{* *}$ & 7 \\
\hline
\end{tabular}

\begin{tabular}{|c|c|c|c|c|c|c|c|c|}
\hline & & & & & & \multicolumn{3}{|c|}{ البعد الثاني: مكافحة التخابر مع الاحتلال } \\
\hline 0.000 & $0.804^{* *}$ & 3 & 0.000 & $0.778^{* *}$ & 2 & 0.000 & $0.759^{* *}$ & 1 \\
\hline 0.000 & $0.839^{* *}$ & 6 & 0.000 & $0.755^{* *}$ & 5 & 0.000 & $0.778^{* *}$ & 4 \\
\hline 0.000 & $0.820^{\text {** }}$ & 9 & 0.000 & $0.849^{* *}$ & 8 & 0.000 & $0.775^{\text {** }}$ & 7 \\
\hline
\end{tabular}

\begin{tabular}{|c|c|c|c|c|c|c|c|c|}
\hline & & & & & & لمقاومة والانتهاء & تعزيز روح & البعد ال \\
\hline 0.000 & $0.807^{\text {** }}$ & 3 & 0.000 & $0.858^{* *}$ & 2 & 0.000 & $0.755^{\text {** }}$ & 1 \\
\hline \multirow[t]{2}{*}{0.000} & $0.851^{\text {** }}$ & 6 & 0.000 & $0.813^{* *}$ & 5 & 0.000 & $0.836^{* *}$ & 4 \\
\hline & & & & & 8 & 0.000 & $0.778^{* *}$ & 7 \\
\hline
\end{tabular}

\begin{tabular}{llllllllc}
\hline & & & & \multicolumn{3}{c}{ (البعد الرابع : } \\
\hline 0.000 & $0.844^{* *}$ & 3 & 0.000 & $0.875^{* *}$ & 2 & 0.000 & $0.791^{* * *}$ & 1 \\
0.000 & $0.816^{* *}$ & 6 & 0.000 & $0.844^{* *}$ & 5 & 0.000 & $0.781^{* *}$ & 4 \\
& & & 0.000 & $0.874^{* *}$ & 8 & 0.000 & $0.871^{* *}$ & 7 \\
\hline
\end{tabular}

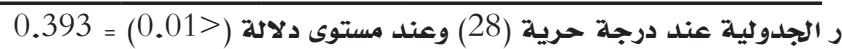

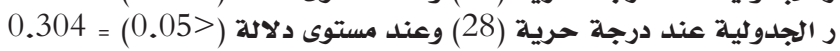

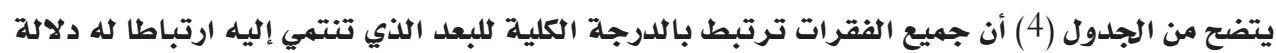

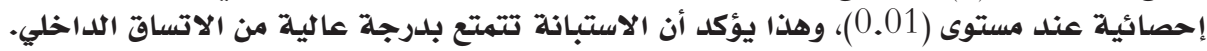

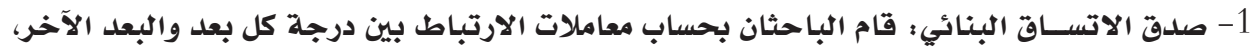

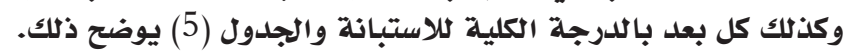

جلدول (5): معامل الارتباط بين كل بعد من أبعاد الاستبانة مع الدرجة الكلية للاستبانة

\begin{tabular}{|c|c|c|c|}
\hline القيهة الاحتهالية sig & معامل الارتباط & البعد البعد & م \\
\hline 0.000 & $0.865^{* *}$ & تعزيز الوعي الوطني & 1 \\
\hline 0.000 & $0.915^{* *}$ & مكافحة التخابر مع الاحتلال & 2 \\
\hline 0.000 & $0.934^{* *}$ & تعزيز روح المقاومة والانتماء & 3 \\
\hline 0.000 & $0.941^{* *}$ & بناء الشخصية الوطنية & 4 \\
\hline
\end{tabular}

ثبات الاستبانة :

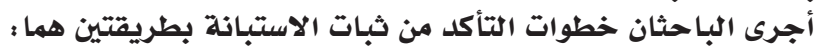

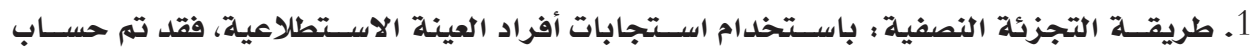

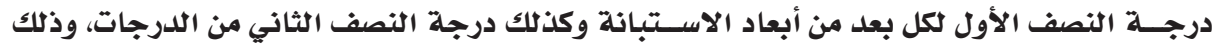

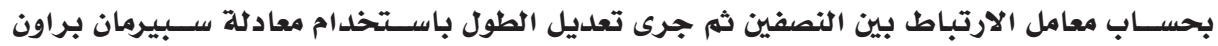


د. محهمود عبد المجيد عساف د. علاء محمد الغهاري

المجلد السابع والعشرون العلدد (2)، مارس 2021م

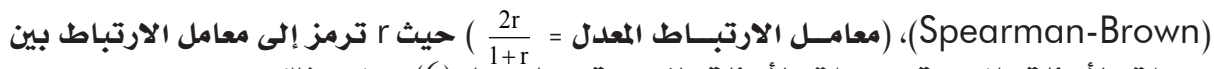

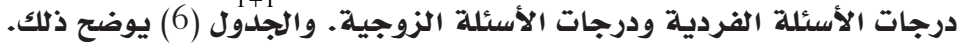

جلدول (6) : معامل الثبات (طريقة التجزئة النصفية) للاستبانة

\begin{tabular}{|c|c|c|c|c|}
\hline \multicolumn{3}{|c|}{ التجزئة النصفية } & \multirow{2}{*}{ 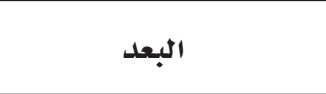 } & \multirow{2}{*}{ م } \\
\hline معامل الارتباط المصحح & معامل الارتباط & عدد الفقرات & & \\
\hline 0.921 & 0.854 & 7 & تعزيز الوعي الوطني & 1 \\
\hline 0.922 & 0.856 & 9 & مكافحة التخابر مع الاحتلال & 2 \\
\hline 0.941 & 0.889 & 7 & تعزيز روح المقاومة والانتماء & 3 \\
\hline 0.941 & 0.889 & 8 & بناء الشخصية الوطنية & 4 \\
\hline 0.983 & 0.967 & 31 & الدرجة الكلية للاستبانة & \\
\hline
\end{tabular}

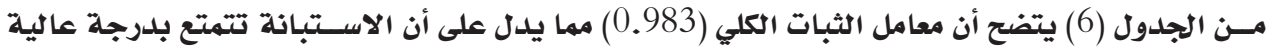

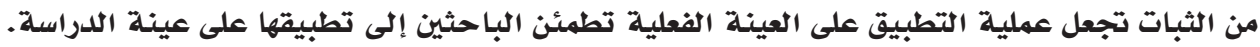

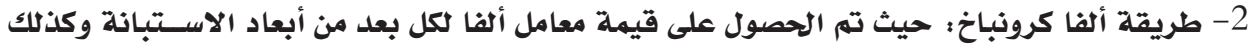

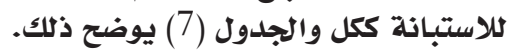

جدول (7): معامل الثبات باستخدام ألفا كرونباخ

\begin{tabular}{|c|c|c|}
\hline معامل الثبات & البعد & م \\
\hline 0.88 & تعزيز الوعي الوطني & 1 \\
\hline 0.93 & مكافحة التخابر مع الاحتلال & 2 \\
\hline 0.92 & تعزيز روح المقاومة والانتماء & 3 \\
\hline 0.94 & بناء الشخصية الوطنية & 4 \\
\hline 0.97 & الدرجة الكلية & \\
\hline
\end{tabular}

من الجدول (7) يتضح أن معامل الثبات الكلي (0.97)، مما يدل على الفئل أن الاستبانة تتمتع بدرجة الفية عالية من الثبات تطمئن الباحثين إلى تطبيقها على العينة الفعلية.

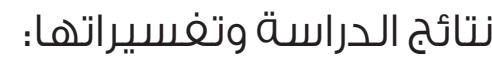

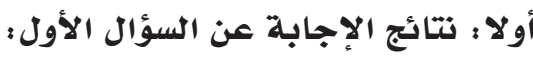
ينص السؤال الأول للدراسة على : "ما درجة تقدير عينة من الإعلاميلاميين والأمنيين لدور مشروع التحصين

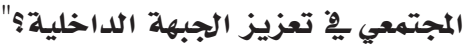

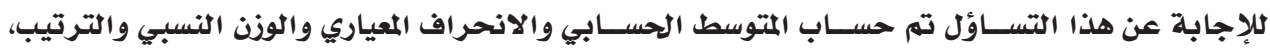

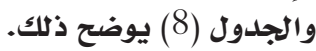

جلدول (8) : النسب المئويـة لدرجة تقدير العينـة للدور مشروع التحصين المجتمعي يِ تعزيز الجبهة الداخلية

\begin{tabular}{|c|c|c|c|c|c|c|}
\hline التقلدير & الترتيب & المئويسة & الانحياري افي & المتوسطابي & 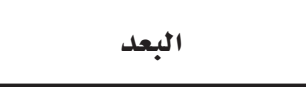 & م \\
\hline كبيرة' & 2 & $\% 81.6$ & 0.588 & 4.08 & تعزيز الوعي الوطني & 1 \\
\hline كبيرة جدا & 1 & $\% 84.8$ & 0.597 & 4.24 & مكافحة التخابر مع الاحتلال & 2 \\
\hline كبيرة: - كبرة & 3 & $\% 81.2$ & 0.678 & 4.06 & تعزيز روح المقاومة والانتماء & 3 \\
\hline كبيرة' - كبرة & 4 & $\% 76.4$ & 0.719 & 3.82 & بناء الشخصية الوطنية & 4 \\
\hline 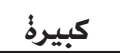 & \multicolumn{2}{|c|}{$\% 81$} & 0.591 & 4.05 & البعد الكلي & \\
\hline
\end{tabular}




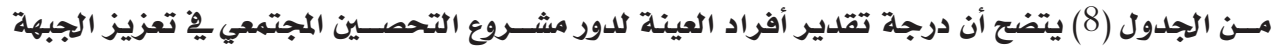

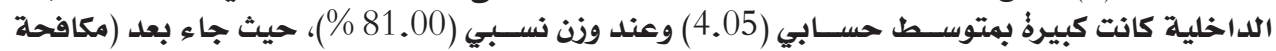

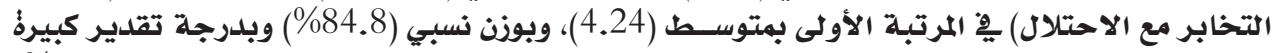

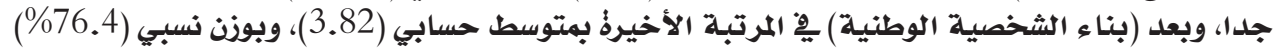

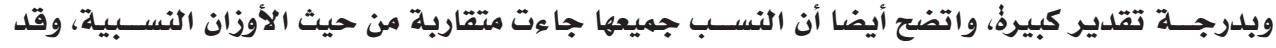

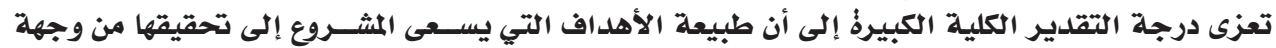

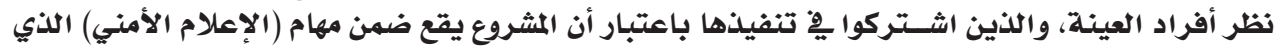

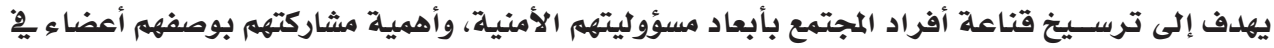

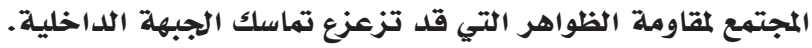

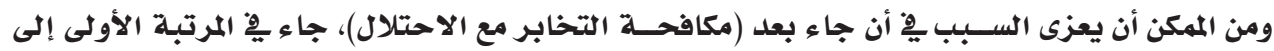

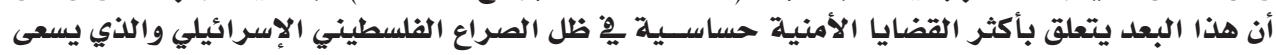

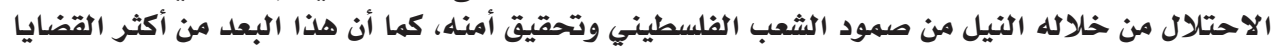

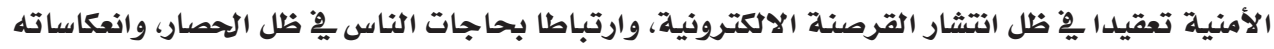

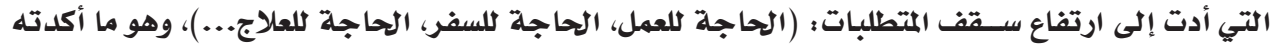
دراسة معهر (2014).

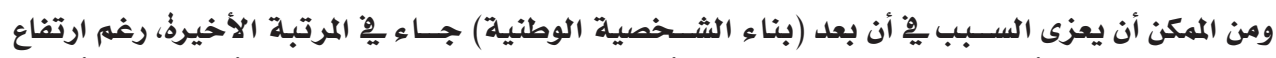

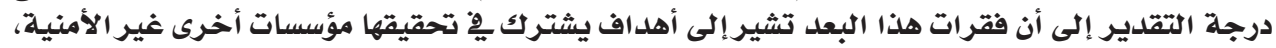

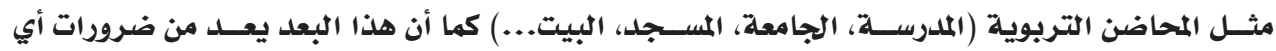

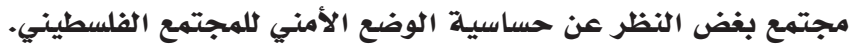
وفيما يلي تحليل أبعاد وفقرات الاستبانة، كل على حلدة :

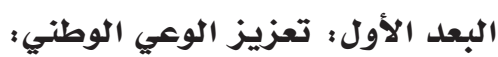

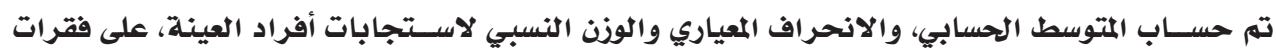

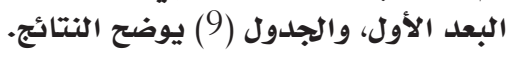
جدول (9) : المتوسط والانحراف والنسبة المئوية والرتب لمحور تعزيز الوعي الوطني

\begin{tabular}{|c|c|c|c|c|c|c|}
\hline الفقديرٌ & الرتبة & المئويةية & الانحياري & الحستوسطي & الفقرة & r \\
\hline كبيرة & 3 & $\% 80.4$ & 0.627 & 4.02 & يسهم المشروع يٌْ التثقيف الوطني من خلال & 1 \\
\hline كبيرة & 4 & $\% 80.2$ & 0.768 & 4.01 & يعزز قيم المشاركة ِِّ خدمة المجتمع. & 2 \\
\hline كبيرة: & 6 & $\% 77.4$ & .833 & 3.87 & يغرس مبادئ احترام القانون والأنظمة & 3 \\
\hline كبيرة: & 5 & $\% 78.4$ & 0.823 & 3.92 & خبرات الآخرين المشروعا الانفتاح والاستفادةٌ من & 4 \\
\hline كبيرة: & ק & $\% 78.4$ & 0.839 & 3.92 & يحذر من كل مظاهر التمييز (الديني، & 5 \\
\hline 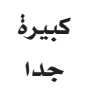 & 2 & $\% 86.6$ & 0.717 & 4.33 & يحذر من الآثار السلبية لبث وترويج & 6 \\
\hline 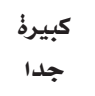 & 1 & $\% 87.8$ & 0.774 & 4.39 & يسهم يفّ رفع الروح المعنوية من خلال كشف الإسيلية. & 7 \\
\hline & \multicolumn{2}{|c|}{$\% 81.6$} & 0.588 & 4.06 & الدرجة الكلية & \\
\hline
\end{tabular}


د. محهمود عبد المجيد عساف د. علاء محمد الغهاري

المجلد السابع والعشرون العدد (2)، مارس 2021 محمد الفمافيل

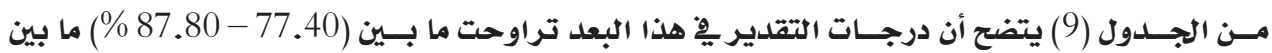

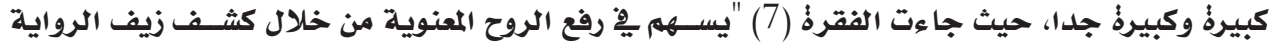

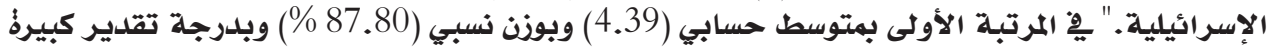

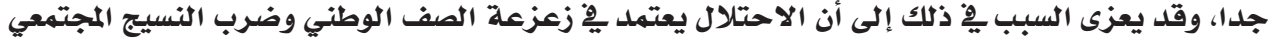

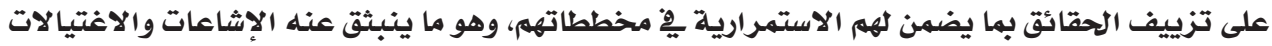

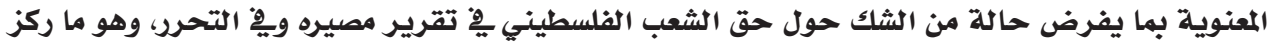

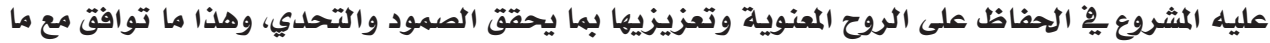

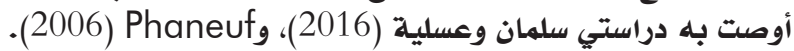

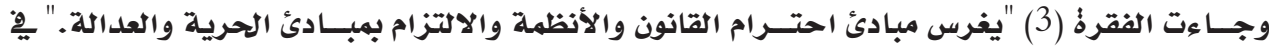

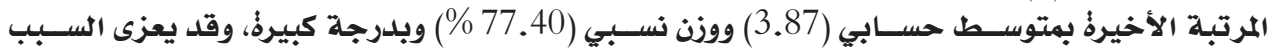

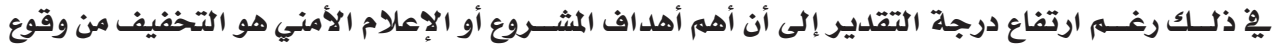

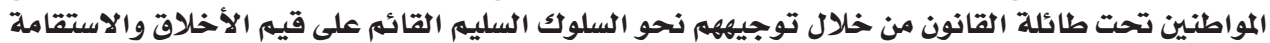
واحترام القوانين والأنظمة، وهو أمر منوط بالإعلام الثامل منامل من باب المساوافٌ. البعل الثاني: مكافحة التخابر مع الاحتثلال:

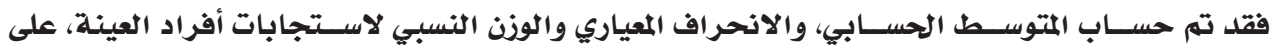

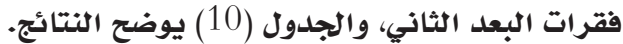

جدول (10): المتوسط والانحراف والنسبة المئوية والرتب لبعد مكافحة التخابر مع الاحتلال

\begin{tabular}{|c|c|c|c|c|c|c|}
\hline تقلفرير & الرتبة & المئوينة & الانحراف & المتوسطابي & الفقرةُ & $\hat{~}$ \\
\hline كبيرة جدا & 1 & $\% 87$ & 0.684 & 4.35 & يوضح أساليب استغلال الاحتلال لاحتياجات & 1 \\
\hline كبيرة: & 6 & $\% 83$ & 0.758 & 4.15 & يعزز الوازع الديني والأخلاقي بما يمنع & 2 \\
\hline كبيرةٌ جدا & 1 & $\% 87$ & 0.789 & 4.35 & يحذر من المخاطر الأمنية لمواقع التواصل & 3 \\
\hline كبيرذٌ جدا & 4 & $\% 84.8$ & 0.770 & 4.24 & يبين طرق الاحتلال يف إضعاف الروح & 4 \\
\hline كبيرةُ جدا & 2 & $\% 86.4$ & 0.826 & 4.32 & يوضح المصير المخزي للعملاء. & 5 \\
\hline كبيرة جدا & 3 & $\% 86$ & 0.696 & 4.30 & والاتصالات الواردذّ من قناطوات مشبوهابة للرسائل. & 6 \\
\hline كبيرة جدا & 5 & $\% 84.8$ & 0.688 & 4.24 & يسهم هِّ رفع مستوى الوعي بالحساسية & 7 \\
\hline كبيرة: & 6 & $\% 83$ & 0.747 & 4.15 & يكشف زيف المعلومات الموجهة عبر وسائل & 8 \\
\hline كبيرة & 7 & $\% 82.2$ & 0.814 & 4.11 & يكثف مخططات الاحتلال يو: إضعاف الجبهة & 9 \\
\hline & \multicolumn{2}{|c|}{$\% 84.8$} & 0.597 & 4.24 & الدرجة الكلية & \\
\hline
\end{tabular}

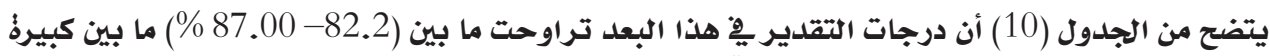

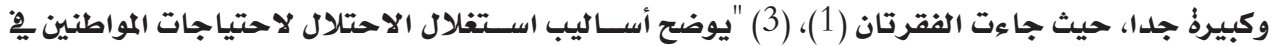

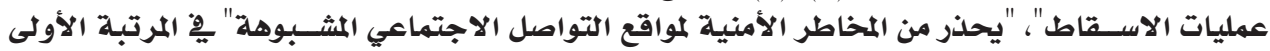

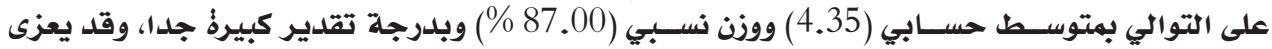




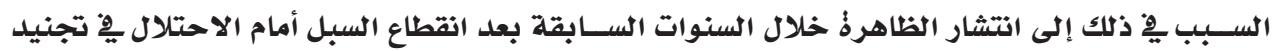

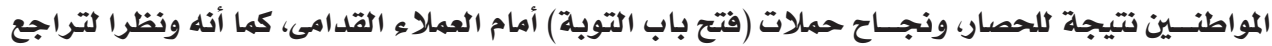

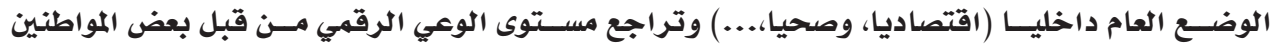

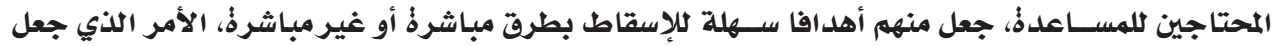

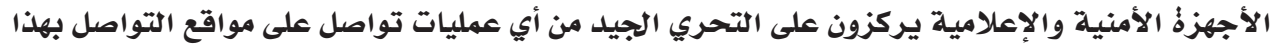

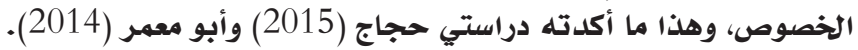

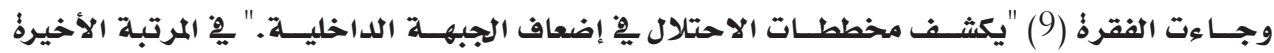

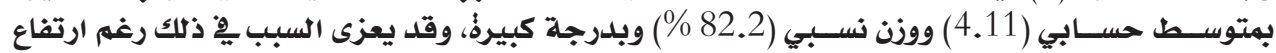

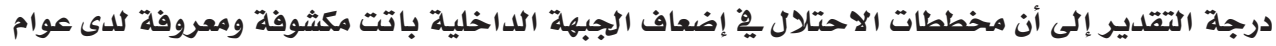

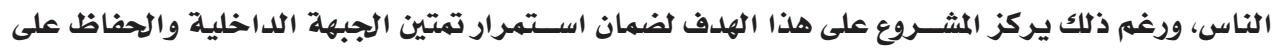

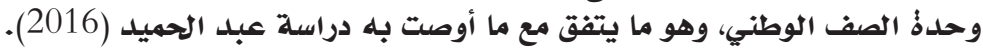
البعد الثالث: تعزيز روح المقاومة والانتماء :

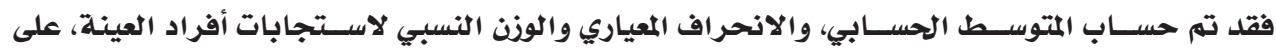

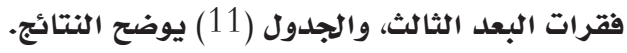
جدول (11): المتوسط والانحراف والنسبة المئوية والرتب لبعد تعزيز روح المقاومة والانتماء

\begin{tabular}{|c|c|c|c|c|c|c|}
\hline تقدرير & الرتبة & المئوينة & الالمعياري & الحتوسط ابي & 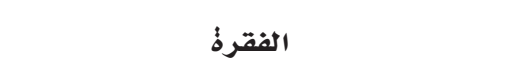 & م \\
\hline كبيرة: & 3 & $\% 83.2$ & 0.751 & 4.16 & يعزز أهمية مواجهة الاحتلال فكريا والكترونيا. & 1 \\
\hline كبيرة جدا & 2 & $\% 84.6$ & 0.841 & 4.23 & يوضح أهمية الالتفاف حول مشروع المقاومة. & 2 \\
\hline كبيرة جدا & 1 & $\% 85.4$ & 0.813 & 4.27 & يؤكد على رفض التطبيع مع الاحتلال. & 3 \\
\hline كبيرة & 6 & $\% 79$ & 0.866 & 3.95 & يعلي من قيمة التضحية يِّ سبيل المشروع الوطني. & 4 \\
\hline كبيرة & 7 & $\% 77.8$ & 0.814 & 3.89 & يوضح مسارات المسئولية الاجتماعية، والفردية. & 5 \\
\hline 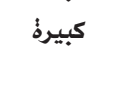 & 4 & $\% 79.4$ & 0.876 & 3.97 & يوظف مواقع التواصل فِ تعزيز روح الانتماء & 6 \\
\hline \multirow[t]{2}{*}{ 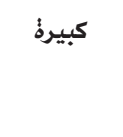 } & 5 & $\% 79.2$ & 0.861 & 3.96 & يؤكد على وحدةُ الغاية من مسيرةُ النضال & 7 \\
\hline & \multicolumn{2}{|c|}{$\% 81.2$} & 0.678 & 4.06 & الدرجة الكلية & \\
\hline
\end{tabular}

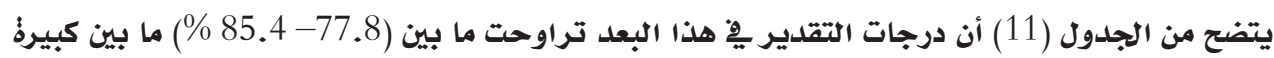

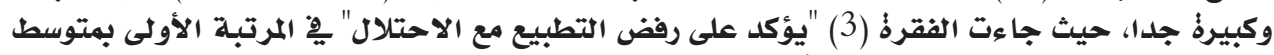

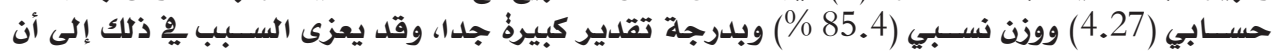

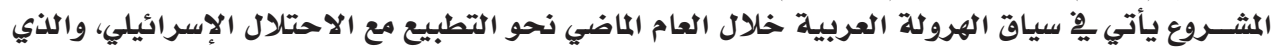

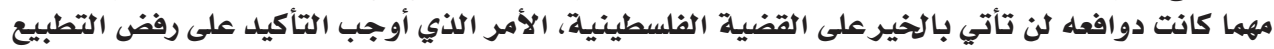
وتوعية الجمهور حول آثاره السلبية على مستقبل القضير القضية الفيلة الفلسطينية.

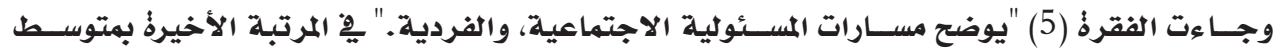

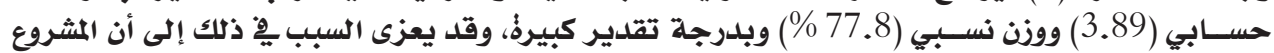

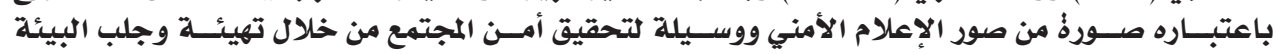

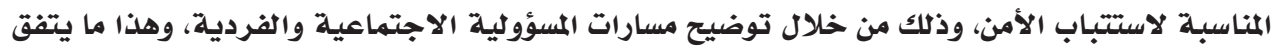

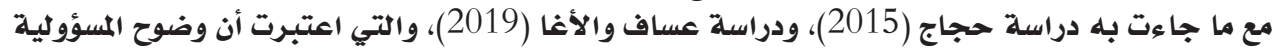
والأدوار المنوطة بالأثخاص من أهم العوامل التي تسهم يِّ تعزيز الجبهة الداخلية. 
د. محهمود عبد المجيد عساف د. علاء محمد الغهاري

المجلد السابع والعشرون العدد (2)، مارس 2021 ملاء معد الفماريد

البعل الرابع: بناء الشخصية الوطنية :

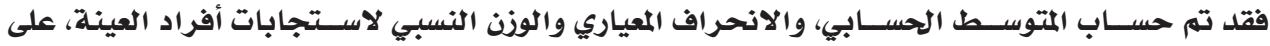

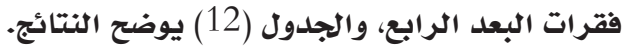
جلدول (12): المتوسط والانحراف والنسبة المئوية والرتب لبعد بناء الشخصية الوطنية

\begin{tabular}{|c|c|c|c|c|c|c|}
\hline الفقرير & الرتبة & المئوية & الانحراف & المتوسطابي & 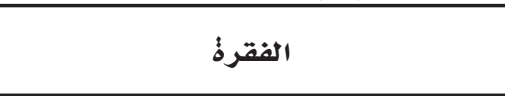 & م \\
\hline كبيرة & 2 & $\% 79.4$ & 0.784 & 3.97 & يسهم بِّ تعزيز مفاهيم تحمل المسؤولية. & 1 \\
\hline كبيرة & 5 & $\% 77.2$ & 0.794 & 3.86 & يدفع يِّ اتجاه تعزيز مهارات التوجيه والإرشاد & 2 \\
\hline كبيرة & 3 & $\% 78.6$ & 0.803 & 3.93 & يعظم من مقومات العمل التوعوي والمجتمعي. & 3 \\
\hline 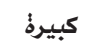 & 8 & $\% 71.2$ & 0.939 & 3.56 & يعزز روح الإبداع والمبادرة. & 4 \\
\hline كبيرة & 7 & $\% 73.0$ & 0.909 & 3.65 & يظهر مميزات الشخصية الوطنية الملتزمة بالدين & 5 \\
\hline كبيرة & 6 & $\% 74.8$ & 0.881 & 3.74 & يشجع على الانخراط ِِّ المشاركة المجتمعية. & 6 \\
\hline كبيرة & 4 & $\% 77.8$ & 0.888 & 3.88 & يوضح القنوات الرسمية الموثوقة (التي تضمن & 7 \\
\hline كبيرة & 1 & $\% 80.8$ & 0.871 & 4.04 & يوضح الأثر السلبي للفراغ ورفاق السوء على السمبلى. & 8 \\
\hline & \multicolumn{2}{|c|}{$\% 76.4$} & 0.719 & 3.82 & الدرجة الكلية & \\
\hline
\end{tabular}

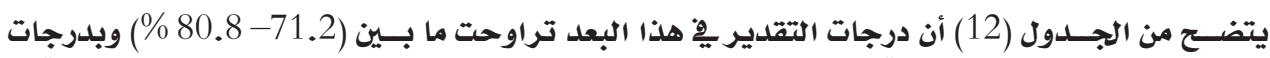

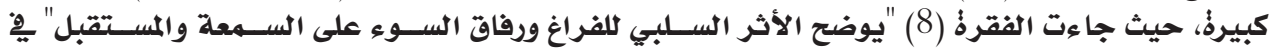

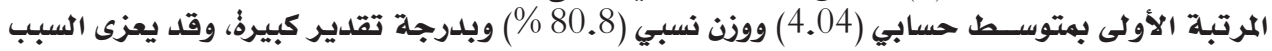

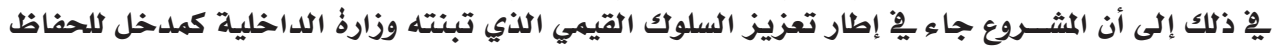

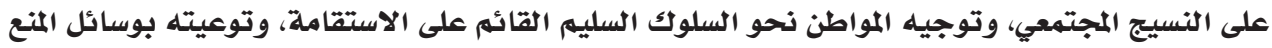

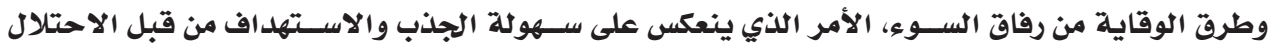
الإسرائيلي، وهذا ما يتفق مع ما جاءت مأ اله دراسة معمر (2014)، ودراسة أبو جحجوح (2012).

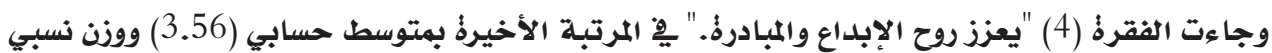

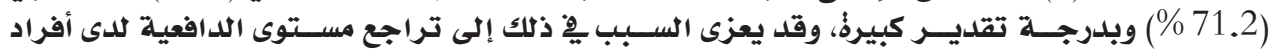

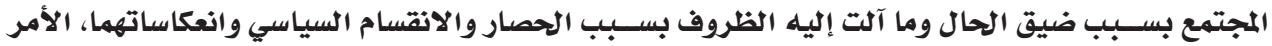

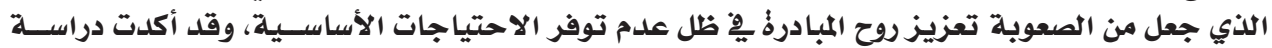
الوحن الموف Duckworth-Loche الحلد من الخوف والحد من العنف.

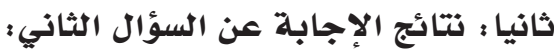

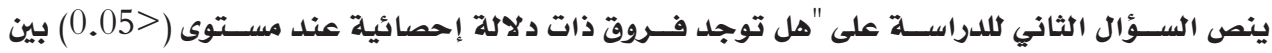

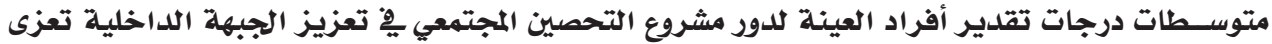

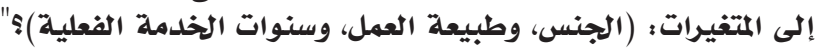

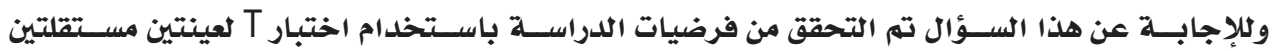
:(Independent Samples T-Test)

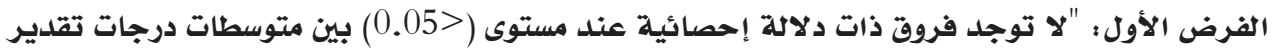

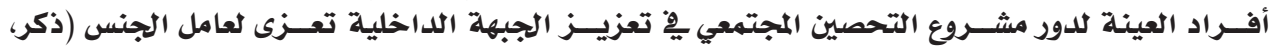

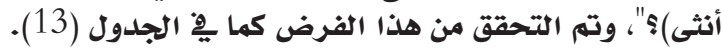


د. محمود عبد المجيل عساف د. د. علاء محمد الغماري

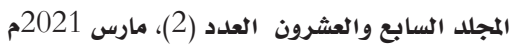

جلدول (13) : اختبار T لإيجاد الفروق بين متوسطات درجات تقدير أفراد العينة تبعا لعامل الجنس (ذكر، أنثى)

\begin{tabular}{|c|c|c|c|c|c|c|}
\hline مستوى الدلاكة & "T" قيمة & الانحراف المعياري & المتوسط & التكرار & الجنس & 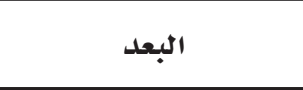 \\
\hline \multirow[t]{2}{*}{0.537} & 0.253 & 0.593 & 4.08 & 108 & ذكر & تعزيز الوعي الوطني \\
\hline & & 0.505 & 3.84 & 10 & أنثى & \\
\hline \multirow[t]{2}{*}{0.642} & 0.468 & 0.596 & 4.25 & 108 & 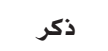 & مكافحة التخابر مع الاحتلال \\
\hline & & 0.633 & 4.15 & 10 & أنثى & \\
\hline \multirow[t]{2}{*}{0.764} & 0.224 & 0.677 & 4.06 & 108 & 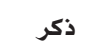 & تعزيز روح المقاومة والانتماء \\
\hline & & 0.720 & 4.01 & 10 & أنثى & \\
\hline \multirow[t]{2}{*}{0.905} & 0.650 & 0.718 & 3.84 & 108 & ذ نكر & بناء الشخصية الوطنية \\
\hline & & 0.757 & 3.68 & 10 & أنثى & \\
\hline \multirow[t]{2}{*}{0.870} & 0.662 & 0.591 & 4.06 & 108 & ذوكر & الدرجات الكلية \\
\hline & & 0.617 & 3.93 & 10 & أنثى & \\
\hline
\end{tabular}

قيمة T الجلدولية عند درجات حرية (116) ومستوى دلالة (>050) تساوي (1.96).

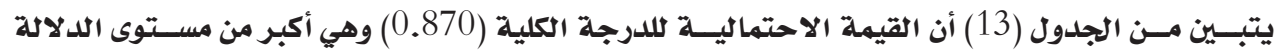

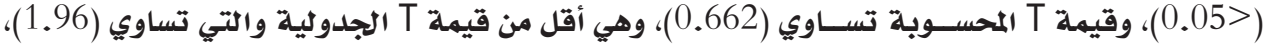

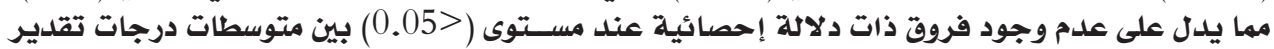

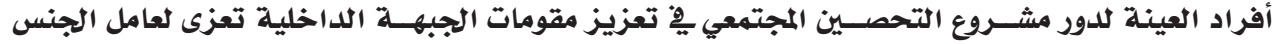

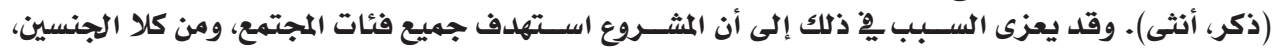

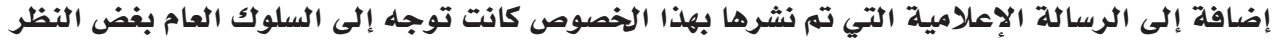

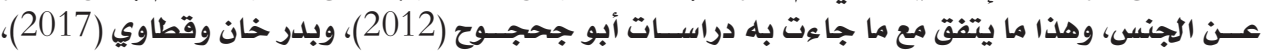

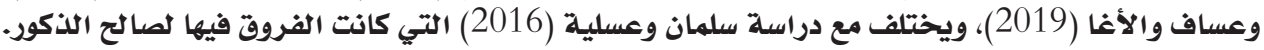

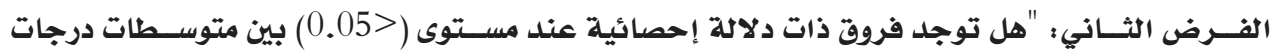

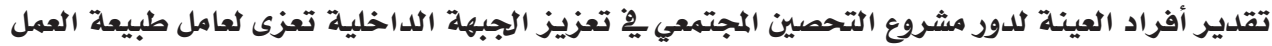

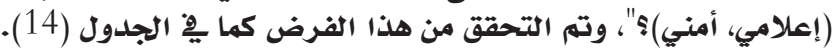
جدول (14): اختبار T لإيجاد الفروق بين متوسطات درجات تقدير أفراد العينة تبعا لعامل طبيعة العمل (إعلامي، أمني)

\begin{tabular}{|c|c|c|c|c|c|c|}
\hline مستوى الدلالة & "T" قيمة & الانحياري & المتوسط & التكرار & طبيعة العمل & 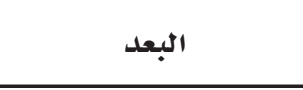 \\
\hline \multirow[t]{2}{*}{0.203} & 0.980 & 0.539 & 4.09 & 93 & أمني & تعزيز الوعي الوطني \\
\hline & & 0.742 & 3.94 & 25 & إعلامي & \\
\hline \multirow[t]{2}{*}{${ }^{*} 0.047$} & 2.077 & 0.555 & 4.28 & 93 & 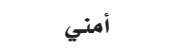 & مكافحة التخابر مع الاحتلال \\
\hline & & 0.732 & 4.11 & 25 & إعلامي & \\
\hline \multirow[t]{2}{*}{${ }^{*} 0.022$} & 2.362 & 0.602 & 4.10 & 93 & أمني & تعزيز روح المقاومة والانتماء \\
\hline & & 0.903 & 3.89 & 25 & إعلامي & \\
\hline \multirow[t]{2}{*}{0.099} & 0.895 & 0.655 & 3.86 & 93 & 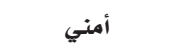 & بناء الشخصية الوطنية \\
\hline & & 0.928 & 3.71 & 25 & إعلامي & \\
\hline \multirow[t]{2}{*}{${ }^{*} 0.043$} & 2.029 & 0.532 & 4.09 & 93 & أمني & الدرجات الكلية \\
\hline & & 0.771 & 3.92 & 25 & إعلامي & \\
\hline
\end{tabular}

* دالة إحصائيا عند مستوى دلالة (0.05). 
د. محهمود عبد المجيد عساف د. علاء محمد الغهاري

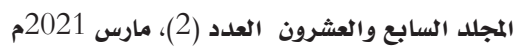

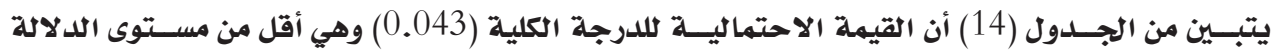

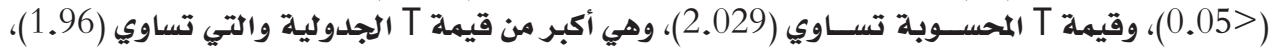

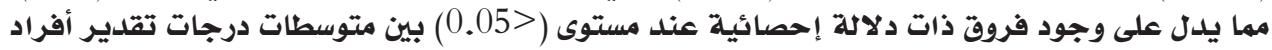

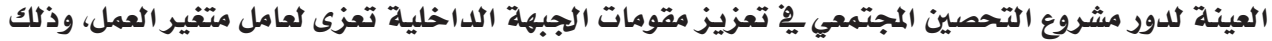

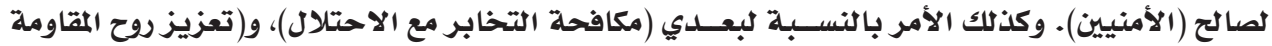

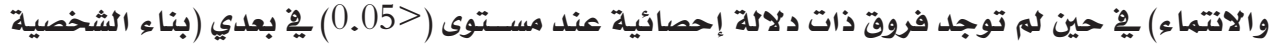
الوطنية)، و(تعزيز الوعي الوطني).

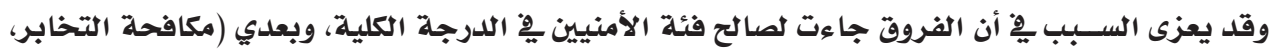

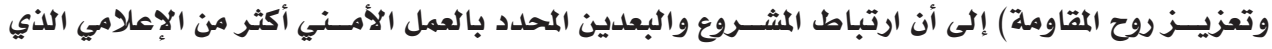

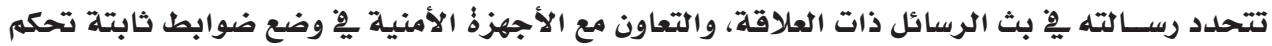

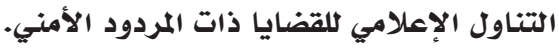

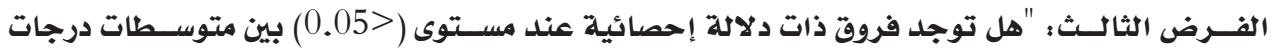

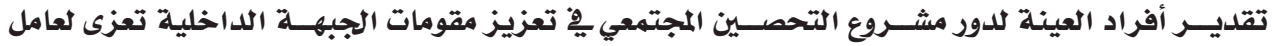

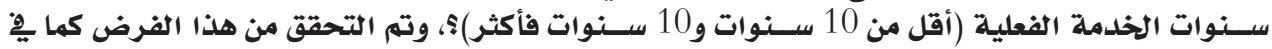

الجدول (15).

جدول (15): اختبار T لإيجاد الفروق بين متوسطات درجات تقدير أفراد العينة تبعا لعامل سنوات الخدمة الفعلية

\begin{tabular}{|c|c|c|c|c|c|c|}
\hline مستوى الدلالة & "T" قيمة & الانحياري & المتوسط & التكرار & سنوات الخلدمة & 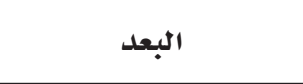 \\
\hline \multirow[t]{2}{*}{0.308} & 0.046 & 0.552 & 4.06 & 33 & أقل من 10 سنوات & تعزيز الوعي الوطني \\
\hline & & 0.605 & 4.06 & 85 & 10 سنوات فأكثر & \\
\hline \multirow[t]{2}{*}{0.274} & 0.485 & 0.537 & 4.23 & 33 & أقل من 10 سنوات & مكافحة التخابر مع الاحتلال \\
\hline & & 0.622 & 4.24 & 85 & 10 سنوات فأكثر & \\
\hline \multirow[t]{2}{*}{0.270} & 0.518 & 0.610 & 4.11 & 33 & أقل من 10 سنوات & تعزيز روح المقاومة والانتماء \\
\hline & & 0.705 & 4.04 & 85 & 10 سنوات فأكثر & \\
\hline \multirow[t]{2}{*}{0.318} & 0.427 & 0.650 & 3.87 & 33 & أقل من 10 سنوات & بناء الشخصية الوطنية \\
\hline & & 0.747 & 3.81 & 85 & 10 سنوات فأكثر & \\
\hline \multirow[t]{2}{*}{0.185} & 0.253 & 0.529 & 4.07 & 33 & أقل من 10 سنوات & الدرجات الكلية \\
\hline & & 0.617 & 4.04 & 85 & 10 سنوات فأكثر & \\
\hline
\end{tabular}

يتبــين من الجدول (15) أن القيمــة الاحتمالية للدرجة الكلية (0.185)، وهي أكبر من مســـوى الدلالة

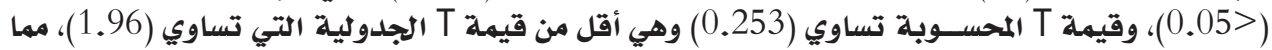

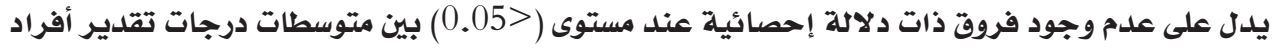

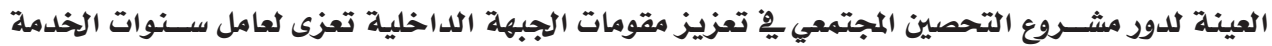

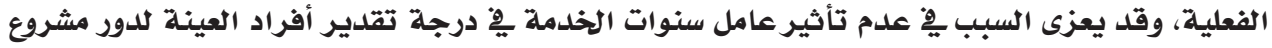

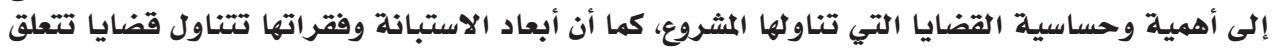

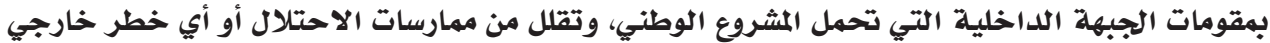

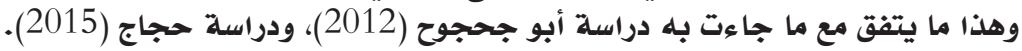

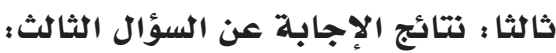

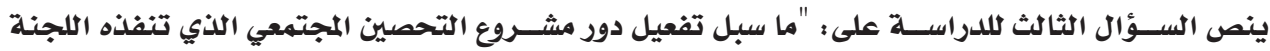

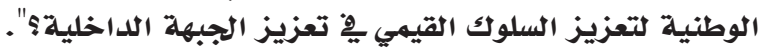




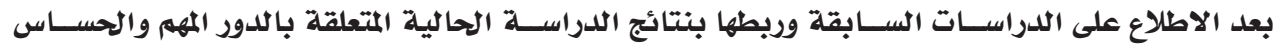

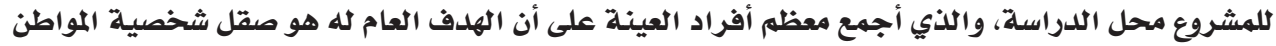

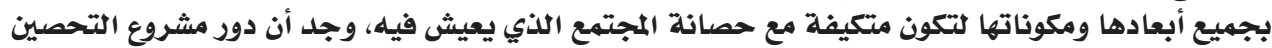

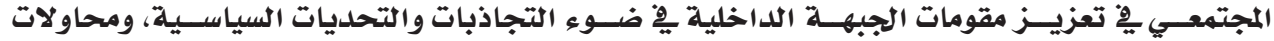

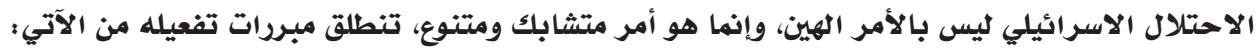

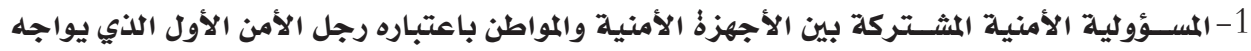

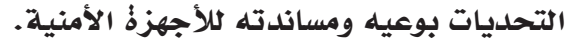
2- الاتجــاه نحو تطوير الرسـالة الإعلامية الأمنية على نحو يواكب ما حظيت به هذه الأه الرســالة من تطور. 3- الصدق يِّ نقل الأخبار أو التعامل مع المعلومات أو الرسـالة الإعلامية دون نقص أو زيادةٌ بما يضمن الشفافية.

4- حمايــة الصف الداخلـي، وتحصينه من خلال التوعيــة بأهمية تعزيز مقومــات الجبهة الداخلية كأساس كلأمن.

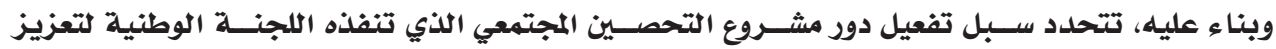

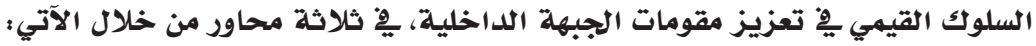

المحور الأمني:

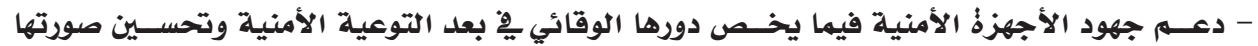

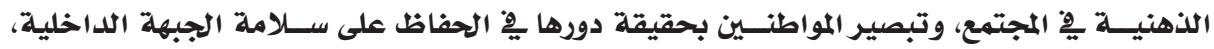
وحماية الأفراد.

- الاستخدام الفعال لكل أدوات النشر والاتصال الإعلامي من قبل الأجهزةٌ الأمنية كأداذُ رئيسة لنجاح استراتيجيات التعزيز القيهي.

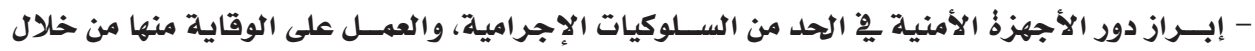

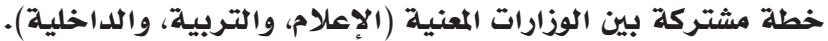

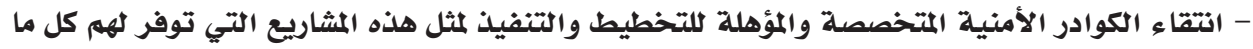

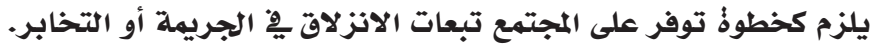

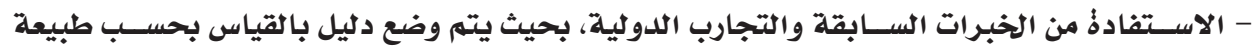

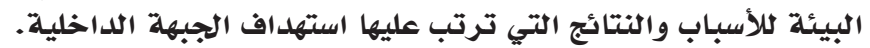

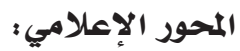

- التنسـيق مع الإذاعات المحلية والفضائيات لتضمين دوراتها البرامجية موادا إعلامية الماتية تتعلق بالتوعية

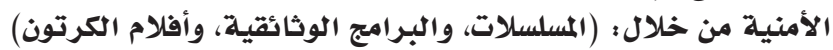

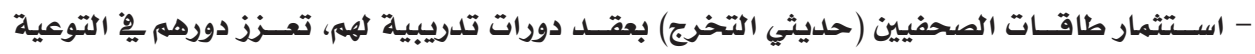

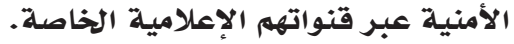

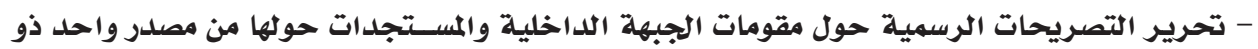

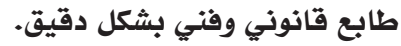

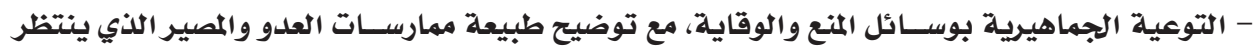

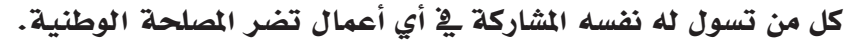

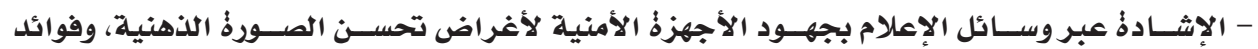

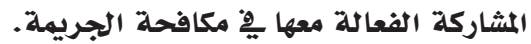


د. محمود عبد المجيد عساف د. دملاء محمد الغماري

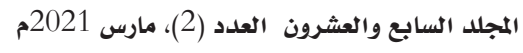

المحور التربوي:

- التنسـيق مع وزارةٌ التربية والتعليه بحيث التويث تتضمن أنثــطة الجامعات والمدارس فعاليات تعزز الثقافة

والوعي الأمني.

- تضمين المناهج الدراسـية الاحتياجات الأمنية المتسـارعة، وما طرأ على أساليب الإسقاط والجريمة

من تطور.

- إعداد دليل إرثادي للمرشلدين التربويين يِّ المدارس لأغراض استكشاف الشخصيات الضعيفة، والعهل

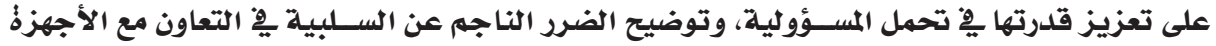

الأمنية.

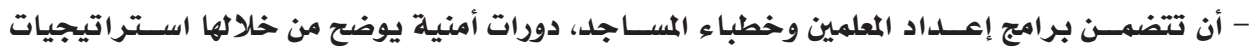

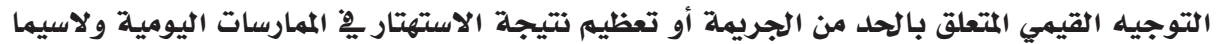

الممارسات الإكترونية منها.

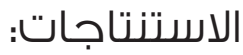

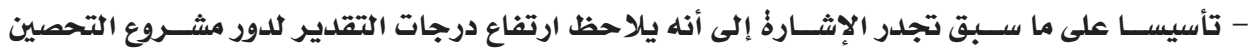

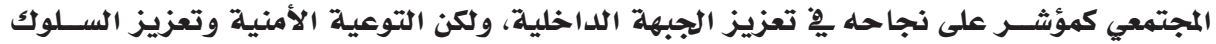

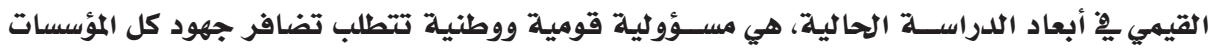

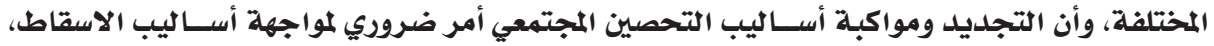

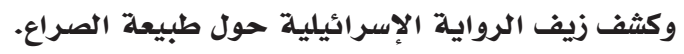

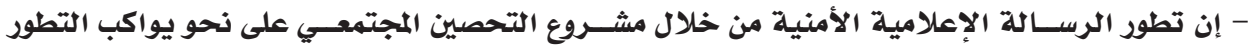

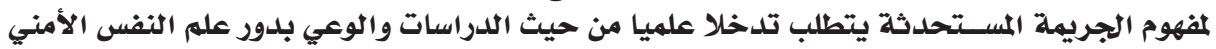

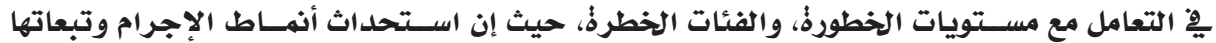

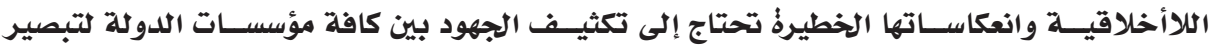

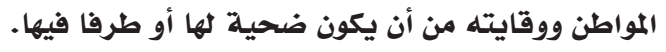

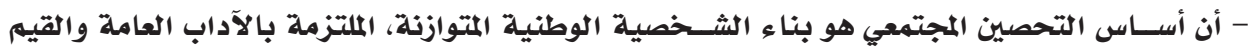

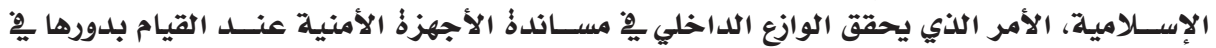

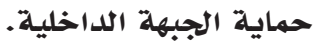

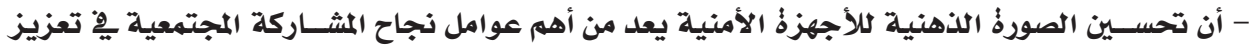

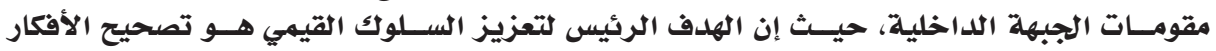

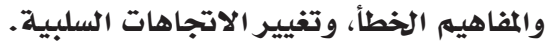

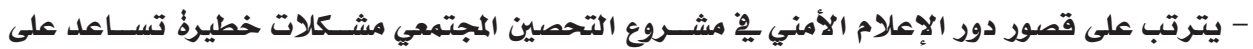

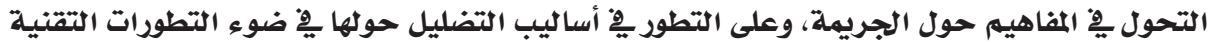

الحمديثة.

التوصيات:

ويف ضوء استنتاجات الدراسة، يوصي الباحثان بالآتي :

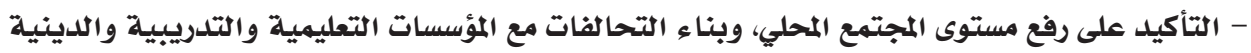

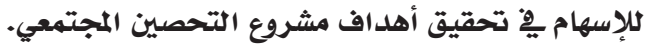

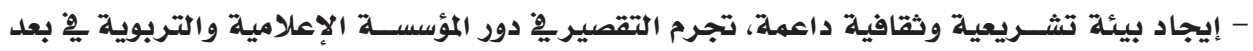
التوعية الأمنية.

- اسـتجلاء المعالم المميزةٌ لثقافة المناخ الأمني والإعلامي الداعم لمقومات الجبهة الداخلية، والتحصين

المجتمعي. 
د. محمود عبد المجيد عساف د. د. علاء محمد الغماري

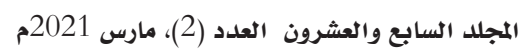

- التخطيط الجيد لأنشطة المشــروع مستقبـا، وتوفير كافة الإمكانات المادية الالازمة لضمان استمراره، واتساع دائرةٌ التأثير.

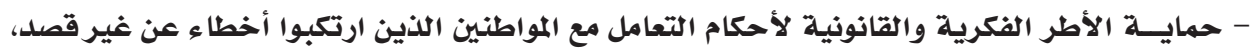
كبعد وقائي للدور الأجهزةٌ الأمنية.

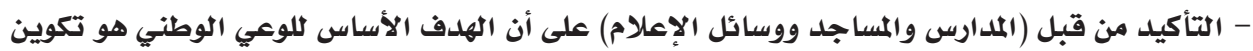

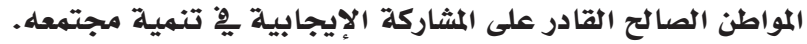

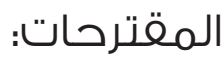

يقترح الباحثان، إجراء الدراسات ِِِ العناوين الآتية :

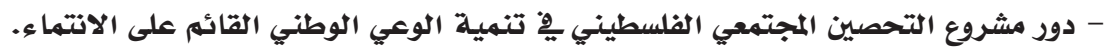

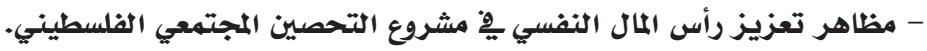

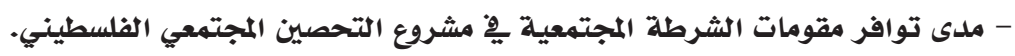

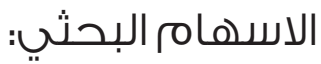

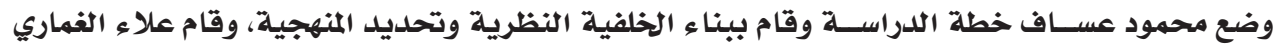

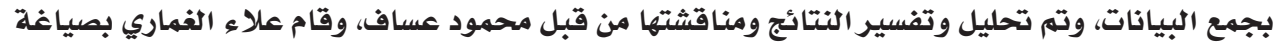

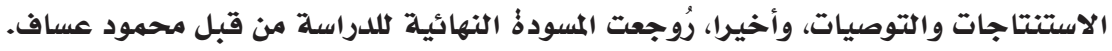

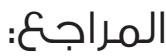
إبراهيم، بيلي (1408هـ)، العمالة الوافلوةُ والمسألة الأمنية، نلدوة التنمية الشاملة وعلاقتها بالأمن، جامعة

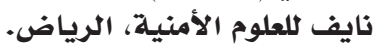

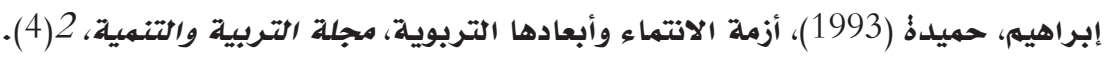

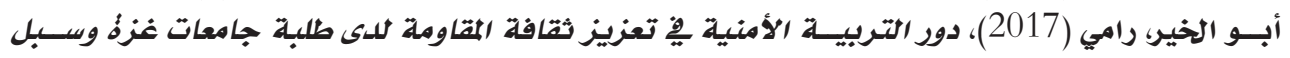

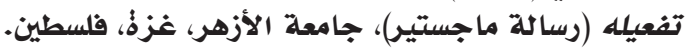

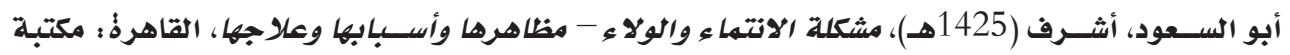
الثقافة الدينية.

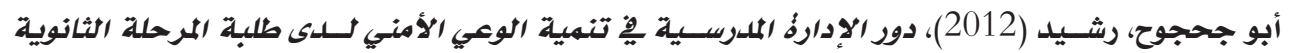

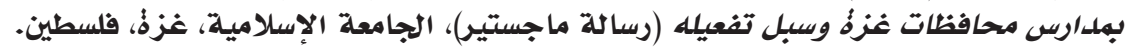

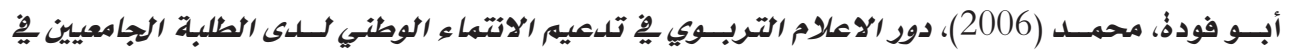

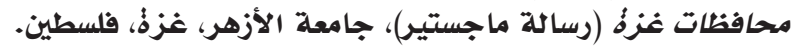

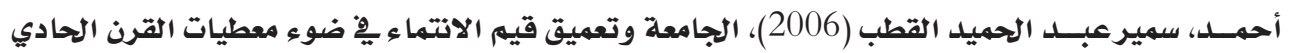

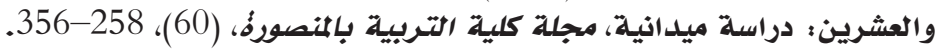

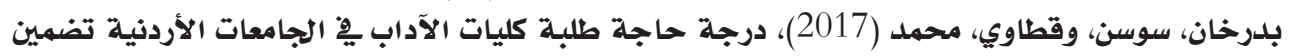

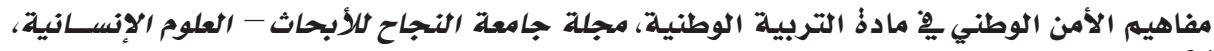

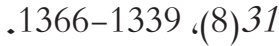

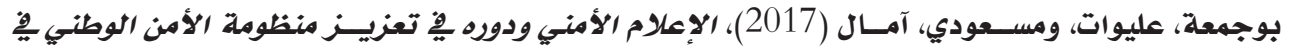

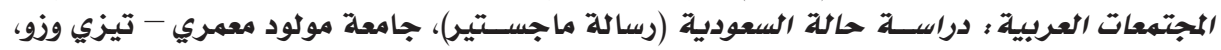
الجزائر. تقى، على عبد المحسن، وطايع، فيصل الراوى (2000)، اتجاهات معاصرةٌ فِ التربية ونظه التعليه، الكويت : مطابع الحسن. الجنحي، علي فايز (2000)، الاعلام الأمني والوقاية من الجرمية، مجلة الأمن، 8(1)، 10-44. 
د. محهمود عبد المجيد عساف د. علاء محمد الغهاري

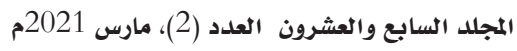

حجاج، نبيل فضل (2015)، دور هيئة التوجيه السياسي والمعنوي فِ تماسك الجبهة الداخلية وسبل تعزيزه (رسالة ماجستير)، جامعة الأقصى، غزةٌ، فلسطين.

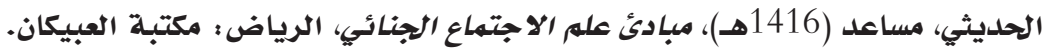

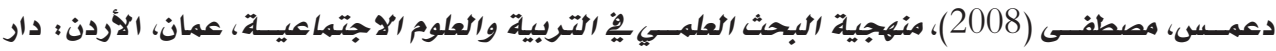
غيداء للنشر والتوزيع.

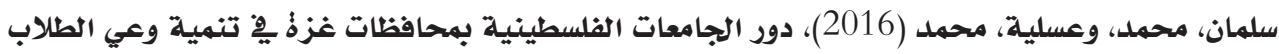
بالثقافة الأمنية لمواجهة المخاطر الأمنية، مجلة جامعة الأقصى (سلسـلة الدراسـات الإنسـانية)، .45-1، 20

الشـرقاوي، موسـى علي (2005)، وعي طلاب الجامعة ببعض قيم المواطنة : دراســة ميدانية، دراسات فِ

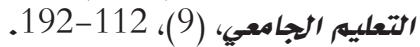

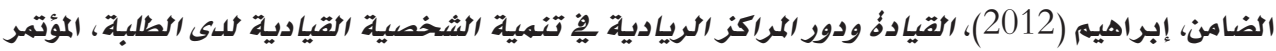

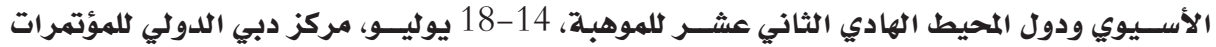
والمعارض، الإمارات العربية المتحول المدادئ.

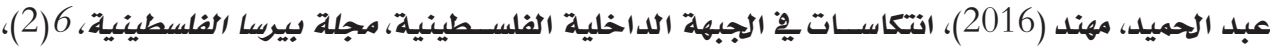
.77-52

عسـاف، محهود (ديسمبر 24، 2020)، التحصين المجتهعي بين الخطاب واللدور، استرجع بتاريخ فبراير 22/20، https://www.amad.ps/ar/post/381760 2021

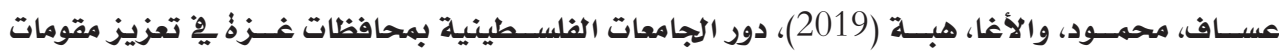

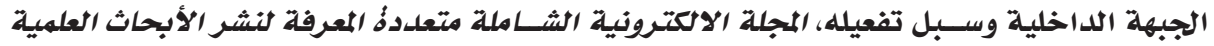

$$
\text { والتربويية، (15)، 1-33. }
$$

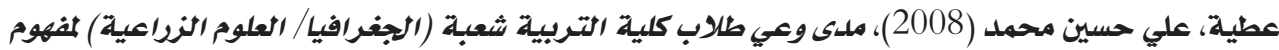

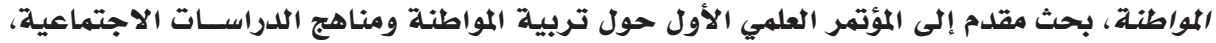

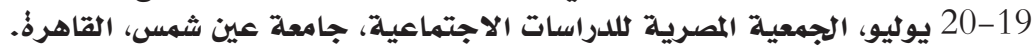

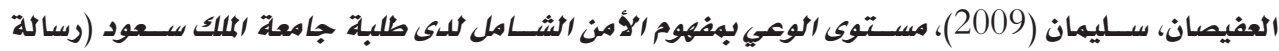

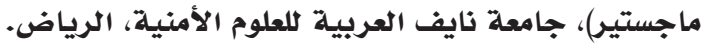

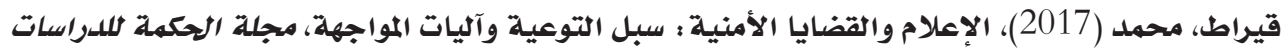

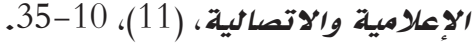

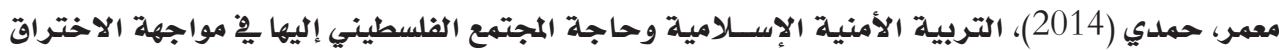

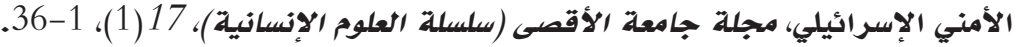

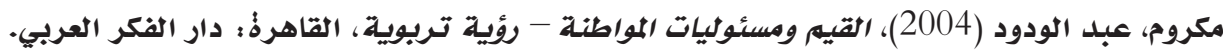

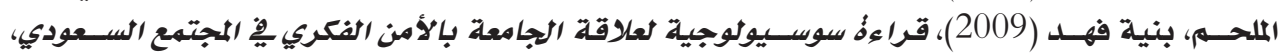

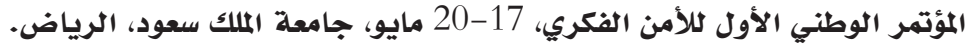

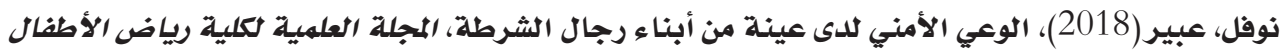

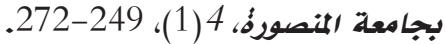

هلال، علي (1986)، تحلديات الأمن القومي العربي فِ العقل القادم، عمان، الأردن ؛ منتلدى الفكر العربي.

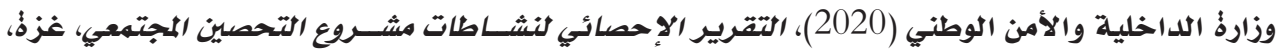
فلسطين.

وكالة الرأي الفلسـطينية (أكتوبر 13، 2020)، "التحصين المجتهعـي" الوقاية من التخابر خيُرئرمن قنطار

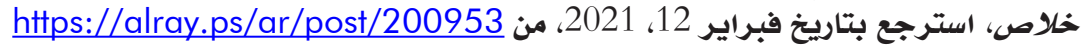


Duckworth-Loche, S. (2000). Perceptions of administrators, counselors, teachers, and students concerning school safety and violence in selected secondary schools in North Lovisiana (Doctoral dissertation). Louisiana Tech University, Ruston, Louisiana.

Martorella, P. H. (1994). Social studies for elementary school children: Developing young citizens. New York: Merrill.

Phaneuf, S. W. (2006). School security practices: Investigating their consequences on student fear, bonding and school climate (Doctoral dissertation). University of Maryland, College Park, Maryland.

Thakur, R. (2004). A political worldview. Security Dialogue, 35(3), 347-348.

\section{Arabic References in Roman Scripts:}

Abdel Hamid, Muhannad (2016). Intikasat fi aljabhat alddakhiliat alfilastiniati, Majalat Birasa Alfilastiniat, 6(2), 52-77.

Abu Al-Khair, Rami (2017). Dawr altarbiat al'amniat fi taeziz thaqafat almuqawamat ladaa talabat Jamieat Ghaza wasubul tafeilih (Resalat majstyr), Jamieat Al'azhar, Ghaza, Filastin.

Abu Al-Saud, Ashraf (1425). Mushkilat alaintima' walwala' - mazahiruha wa'asbabuha waeilajiha, Alqahrt: Maktabat althaqafat aldiyniat.

Abu Fouda, Muhammad (2006). Dawr al'iielam altarbawii fi tadeim alaintima' alwatanii ladaa altalabat aljamieiiyn fi muhafazat Ghaza (Resalat majstyr), Jamieat Al'azhar, Ghaza, Filastin.

Abu Jahjouh, Rashid (2012). Dawr al'idarat almadrasiat fi tanmiat alwaey al'amnii ladaa talabat almarhalat alththanawiat bimadaris muhafazat Ghaza wasubul tafeilih (Resalat majstyr), Aljamieat Al'iislamiati, Ghaza, Filastin.

Adams, Mustafa (2008). Manhajiat albahth aleilmii fi altarbiat waleulum alaijtimaeiati, Oman, Al'urdun: Dar Ghayda' Lilnashr Waltawzie.

Ahmed, Samir Abdel-Hamid Al-Qutb (2006), Aljamieat wataemiq qiam alaintima' fi daw' muetiat alqarn alhadi waleishrina: Dirasat midaniatin, Majalat Kuliyat Altarbiat Bialmansurat, (60), 258-356.

Al-Damen, Ibrahim (2012). Alqiadat wadawr almarakiz alryadyt fi tanmiat alshakhsiat alqiadiat ladayi altalabat, Almutamar Al'asiawii wa Dual Almuhit Alhadii Althany Ashr Lilmawhibati, 14-18 Yuliu, Markiz Dubay Alduwaliu Lilmutamarat wa Almaaridh, Al'iimarat Alearabiat Almutahadati.

Al-Hadithi, Musaed (1416). Mabadi eilm alaiitimae aljanayiyi, Alriyad: Maktabat Aleubykan. 


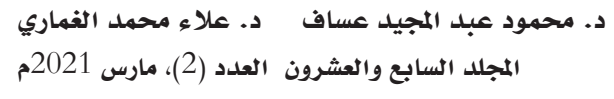

Al-Janahi, Ali Fayez (2000). Al'iielam al'amniu walwiqayat min aljarmiati, Majalat Al'amin, 8(1), 10-44.

Al-Melhem, Bunia Fahd (2009). Qara'at susyulujiatan lialaqat aljamieat bial'amn alfikrii fi almujtamae alsaeudii, Almutamar Alwatanii Al'awal Lil'amn Alfikrii, 17-20 Mayu, Jamieat Almalik Sueud, Alriyad.

Al-Sharqawi, Musa Ali (2005). Waey tullab aljamieat bibaed qiam almuatnt: Dirasat midaniat, Dirasat fi Altalim Aljamiei, (9), 112-192.

Al-Ufaisan, Suleiman (2009). Mustawaa alway bimafhum al'amn alshshamil ladaa talabat Jamieat Almalik Sueud (Resalat majstyr), Jamieat Nayif Alarabiat Lileulum Al'amniati, Alriyad.

Assaf, Mahmoud (Dysmbir 24, 2020). Altahsin almujtamiei bayn alkhitab waldawri, Ostarjae bitarikh Fibrayir 22, 2021, min https://www.amad.ps/ar/post/381760

Assaf, Mahmoud, wa Al-Agha, Heba (2019). Dawr aljamieat alfilastiniat bimuhafazat Ghaza fi taziz muqawimat aljabhat alddakhiliat wasubul tafeilihi, Almajalat Al'iiliktruniat Alshshamilat Mutaeadidat Almaerifat Linashr Al'abhath Aleilmiat Waltarbiwiat, (15), 1-33.

Attia, Ali Hussein Muhammad (2008). Mada waey tullab Kuliyat Altarbiat shueba (aljughrafia/ aleulum alziraeiatu) limafhum almuatinati, Bahath muqadim 'iilaa Almutamar Aleilmii Al'awal hawl Tarbiat Almuatinat wa Manahij Aldirasat Alaijtimaeiat, 19-20 Yuliu, Aljameiat Almisriat Lildirasat Alaijtimaeiati, Jamieat Ayan Shams, Alqahira.

Badrakhan, Sawsan, wa Qatawi, Muhammad (2017). Darajat hajat talabat Kuliyat Aladab fi Aljamieat Al'urduniyat tadmin mafahim al'amn alwatanii fi madat altarbiat alwataniati, Majalat Jamieat Alnajah Lil'abhath - Aleulum Al'iinsaniat, 37(8), 1339-1366.

Boujmaa, Eliouat, wa Massoudi, Amal (2017). Al'iielam al'amniu wadawrih fi taziz manzumat al'amn alwatanii fi almujtamaeat alearabiati: Dirasat halat Alsewdyia (Resalat majstyr), Jamieat Mawlud Maeamari - Tayzi Wazu, Aljazayir.

Hajiaj, Nabil Fadl (2015). Dawr Hayyat Altawjih Alsiyasii wa Almaenawii fi tamasuk aljabhat alddakhiliat wasubul taezizih (Resalat majstyr), Jamieat Al'aqsaa, Ghaza, Filastin.

Hilal, Ali (1986). Tahadiyat al'amn alqawmii alarabii fi alaqd alqadimi, Oman, Al'urdun: Muntadaa Alfikr Alarabi.

Ibrahim, Bailey (1408). Alamalat alwafidat walmas'alat al'amniatu, Nadwat Altanmiat Alshshamilat wa Alaqatuha Bil'amini, Jamieat Nayif Lilulum Al'amniati, Alriyad.

Ibrahim, Hamida (1993). 'Azmat alaintima' wa'abeaduha altarbawiatu, Majalat Altarbiat Waltanmiat, 2(4). 
Makroum, Abdel-Wadood (2004). Alqiam wamasyuwliaat almuatinat: Ruyat tarbawiatu, Alqahirat: Dar Alfikr Alarabi.

Muammar, Hamdi (2014). Altarbiat al'amniat al'iislamiat wahajat almujtamae alfilastinii 'iilayha fi muajahat alaikhtiraq al'amnii al'iisrayiylii, Majalat Jamieat Al'aqsaa (Silsilat Alulum Al'iinsaniat), 17(1), 1-36.

Nofal, Abeer (2018). Alwaey al'amniu ladaa ayinat min 'abna' rijal alshurtati, Almajalat Alilmiat li Kuliyat Riad Al'atfal bi Jamieat Almansurat, 4(1), 249272.

Qirat, Muhammad (2017). Al'iielam walqadaya al'amniatu: Subul altaweiat waliat almuajahati, Majalat Alhikmat Lildirasat Al'iielamiat Walaitisaliat, (11), 10-35.

Salman, Muhammad, wa Aslia, Muhammad (2016). Dawr aljamieat alfilastiniat bimuhafazat Ghazat fi tanmiat waeyi altullab bialthaqafat al'amniat limuajahat almakhatir al'amniati, Majalat Jamieat Al'aqsaa (Silsilat Aldirasat Al'iinsaniat), 20(1), 1-45.

Taqi, Ali Abdul-Muhsin, wa Tayie, Faisal Al-Rawi (2000). Aitijahat mueasarat fi altarbiat wanuzim altaelimi, Alkuayta: Matabie Alhusn.

Wikalat Alraay Alfilastinia (Okatubr 13, 2020). "Alitahsin almujtmey" alwiqayat min altakhabur khayrun min qintar khalas, Ostarjae bitarikh Fibrayir 12, 2021, min https://alray.ps/ar/post/200953

Wizarat Alddakhiliat wa Al'amn Alwatanii (2020). Altaqrir al'iihsayiya linashatat mashrue Altahsin Almuitamei, Ghaza, Filastin. 